\title{
Can Prunus serotina be Genetically Engineered for Reproductive Sterility and Insect Pest Resistance?
}

\author{
Ying Wang $\cdot$ Paula M. Pijut
}

Received: 26 June 2014/Revised: 10 September 2014/Accepted: 18 October 2014/Published online: 1 November 2014

(C) Springer International Publishing AG (outside the USA) 2014

\begin{abstract}
Black cherry (Prunus serotina) is a valuable hardwood timber species, and its value highly depends on the wood quality which is often threatened by insect pests. Transgenic black cherry plants that are more resistant to cambial-mining insects may reduce the occurrence of gummosis and have great economic benefits to landowners and the forest products industries utilizing black cherry lumber and logs. In this review, general information about black cherry and the problem of gummosis are introduced. The various strategies for gene containment, the possibility of using cyanogenesis to enhance host resistance, and the current status of micropropagation, adventitious shoot regeneration, rooting, and Agrobacterium-mediated transformation in P. serotina and several other Prunus species are briefly discussed.
\end{abstract}

Keywords Agrobacterium - Cyanogenesis - Flowering · Gummosis · In vitro culture $\cdot$ Prunus $\cdot$ Reproductive sterility $\cdot$ Transgene containment

Endorsed by Paula M. Pijut.

\footnotetext{
Y. Wang

Department of Forestry and Natural Resources, Hardwood Tree Improvement and Regeneration Center (HTIRC), Purdue University, 715 West State St., West Lafayette, IN 47907, USA

P. M. Pijut ( $\square)$

USDA Forest Service, Northern Research Station, HTIRC, 715

West State St., West Lafayette, IN 47907, USA

e-mail: ppijut@fs.fed.us
}

\section{Black Cherry}

Black cherry (Prunus serotina Ehrh.), also known as wild black cherry, rum cherry, and mountain black cherry, is the only member in the genus Prunus that is of commercial importance as a timber species [96]. It is native to North America and is widely distributed throughout the eastern United States [28]. There are five varieties that are usually recognized based on the height of the tree and the thickness of the leaves: (1) P. serotina var. eximia (Small) Little; (2) $P$. serotina var. rufula (Woot. \& Standl.) McVaugh; (3) $P$. serotina var. virens (Woot. \& Standl.) McVaugh; (4) $P$. serotina var. salicifolia (Kunth) Koehne; and (5) P. serotina var. serotina. Among them, $P$. serotina var. serotina is the most common and widespread variety in the eastern United States and Canada [126]. Black cherry is one of the most valuable hardwoods for cabinets, furniture, veneer, architectural millwork, and musical instruments [93]. However, large and high-quality trees suited for commercial use (belonging to var. serotina) are only found in a restricted area on the Allegheny Plateau of Pennsylvania, New York, and West Virginia [57, 92].

Black cherry (subgenus Padus) is a deciduous and monoecious tree with moderate size. The leaves are 5-13$\mathrm{cm}$ in length and elliptical with serrated leaf margins. Its elongated racemes are small and have numerous white, perfect flowers in a leafy shoot, and its fruits are fleshy [14]. The fruits are acyanogenic throughout the developmental stages as they lack the catabolic enzymes, whereas the seeds become highly cyanogenic during the process of maturation with the accumulation of both the catabolic enzymes and cyanogenic glycosides [166]. Black cherry grows best in areas that are cool, moist, and temperate [41]. Black cherry serves as a host to a large number of pathogens. It is susceptible to soil-borne pathogens that are 
particularly Pythium spp. Pythium spp. have a wide host range and can cause damping-off, root rot, and death of seedlings [115, 145]. Packer and Clay [116] reported the negative effects of this fungal pathogen on the mortality and growth rate of black cherry seedlings. The fungus, Apiosporina morbosa, infects a variety of Prunus spp. including black cherry. It infects twigs or branches which eventually form rough, brown-to-black galls (black knots) on twigs and branches [195]. The disease severely weakens the tree, increases the potential of insect attack, and causes significant production loss [11]. Another common disease on black cherry is cytospora canker caused by Cytospora leucostoma. The first external symptom is the production of amber-colored gum at the site of the infection [146]. Cankers extend with the growth of the fungus, and the infected twigs or branches will eventually be killed.

The genome of black cherry has not been sequenced, and molecular genetic or genomic studies on this tree species are limited. However, information on Rosaceae genomics, genetics, and breeding data, along with other genetic tools are publically available ([19]: Genome Database for Rosaceae, http://www.rosaceae.org/). The genome sequences combined with annotated expressed sequence tag databases of other Prunus species provide useful information to advance research on black cherry. Black cherry is a tetraploid $(2 n=32)$ and is an allotetraploid [138]. Downey and Iezzoni [28] investigated the genetic diversity of 66 black cherry accessions with simple sequence repeats (SSRs) originally developed from sour cherry (P. cerasus L.), peach (P. persica L. Batsch), and sweet cherry $(P$. avium L.). Petitpierre et al. [126] studied chloroplast DNA variation in $P$. serotina var. serotina using restriction fragment length polymorphism (RFLP) markers to detect its colonization routes in Europe. In addition to sweet cherry, the close relatives of black cherry in Prunus include P. laurocerasus L. [161], P. caroliniana Aiton, P. ilicifolia (Nutt.) Walp. ssp. lyonii (Eastw.) Raven, $P$. virginiana L., and European bird cherry (P. padus L.) [15], based on the studies of phylogeny of Prunus using their morphological characters and sequence data from nuclear internal transcribed spacer of ribosomal genes (ITS) and the chloroplast $t r n L-t r n F$ spacer DNA.

\section{Gummosis and Its Control}

As an important timber species, black cherry is threatened by fungal pathogens, insect attack, mechanical wounding, and abiotic stresses that cause the deposition of gum in the bark. This non-specific defense mechanism called gummosis is prevalent in the Rosaceae family [11]. The damage caused by cambial-mining insect pests is the major cause of gum defects. These woodborers include the peach bark beetle (Phloeotribus liminaris Harris), the lesser and greater peachtree borers (Synanthedon pictipes and $S$. exitiosa, respectively), and the agromyzid cambium miner (Phytobia pruni Gross.). Peach bark beetles, for example, make hibernating galleries in the fall and feed on the phloem in the spring [68]. At the mating season in early spring, females make galleries and deposit eggs [11]. Feeding of these pests triggers gummosis. Sometimes the hibernating galleries constructed by the peach bark beetles even cause the gum flow [68]. Gum consists of polysaccharides and a small amount of other substances, and is believed to be induced by ethylene and jasmonic acid (JA) [151]. Secretion of resinous gum largely decreases veneer quality of black cherry trees and their value by $90 \%$ [11]. The cambial-mining insects usually prefer to attack injured and weakened black cherry trees. However, unsuccessful attacks from these pests to healthy trees are also very common [68], which leads to the production of gum. Therefore, effective means of cultural control includes avoiding injury and environmental stresses, reducing the feeding source by minimizing freshly cut wood, trees with wounds, and infested trees. Application of pesticides is only effective when insects are chewing into the bark [11]. Thus, improving the broad-spectrum host resistance of black cherry could be a potentially effective approach. To achieve this goal, genetic engineering has several advantages compared to traditional breeding of woody species. It avoids the long juvenile period of trees and enables transfer of desired traits into superior genotypes [19].

\section{Reproductive Sterility}

The first genetically modified (GM) crop was approved for commercial production in 1994. To date, however, the production of GM trees is still a controversial topic partly because their long life span makes the potential risk to the environment hard to predict. Therefore, it is recommended that gene containment in black cherry be achieved, since transgene flow is an environmental concern and will likely be required by regulatory agencies regarding planting of transgenic trees. Various strategies for transgene containment have been developed, including chloroplast transformation for maternal inheritance, tissue-specific gene excision, approaches targeting reproductive structures or seed formation and germination, and RNA silencing of genes involved in floral initiation and development. There are a number of genes that control this process, and with their function fully understood, more and more could be targeted for intervention. Moreover, multiple strategies could be combined when particular caution is required to increase the effectiveness of containment [71]. 
Strategies for Transgene Containment

\section{Maternal Inheritance}

Maternal inheritance is the method of introducing transgenes into the plastids (chloroplast) to avoid gene flow through pollen transmission. Plastid inheritance in most of the angiosperms is maternal, although very low levels of paternal inheritance have been observed [56, 147]. This approach is useful for outcrossing species, and the high level of gene expression would not induce gene silencing mechanisms [54]. Chloroplast transformation has been widely used for various purposes, such as resistance traits, modification of metabolic pathways, and pharmaceutical production [13]. For example, Kiani et al. [63] used this strategy to express a chloroplast-targeted recombinantBacillus thuringiensis (Bt) gene CrylAc in cotton (Gossypium hirsutum $\mathrm{L}$.) for insect resistance. Yabuta et al. [188] successfully improved vitamin E quality and quantity in tobacco (Nicotiana tabacum cv. Xanthi) and lettuce (Lactuca sativa L. cv Green Wave) by overexpressing the Toc cyclase (TC) or $\gamma$-Toc methyltransferase $(\gamma$-TMT) gene and the TC plus $\gamma$-TMT genes as an operon in the plastid genome. Maldaner et al. [87] used the lettuce plastid transformation system to express dengue virus tetra-epitope peptide antigen production for potential use in dengue diagnosis. Although the chloroplast genome is highly conserved among most land plants, the chloroplast genome sequence data, especially the intergenic spacer regions and endogenous regulatory sequences, is essential for chloroplast transformation to achieve efficient site-specific integration via homologous recombination and optimal expression of foreign genes, respectively [22]. To date, there are about 274 chloroplast genomes that have been completely sequenced, which greatly facilitates the development of this technique (NCBI Organelle Genome, http:// www.ncbi.nlm.nih.gov/genome). However, peach is the only Prunus species that has been sequenced for its chloroplast genome. In addition, the evaluation of several studies using chloroplast transformation for gene containment showed low percentage of pollen outcrossing [48].

\section{Male Sterility, Complete Sterility, and Seed Sterility}

Male sterility interferes with the development of pollen. Anthers have been the target organ of many studies. Mariani et al. [91] reported tissue-specific expressed chimeric ribonuclease in the anthers of tobacco and oilseed rape (Brassica napus cv. Drakkar) plants, and pollen formation was prevented as a result of the destruction of the tapetal cell layer that surrounds the pollen sac. Worrall et al. [186] reported that secretion of a modified vacuolar beta-1,3glucanase from the tapetum prior to the appearance of normal callase activity in the locule could lead to premature dissolution of the callose walls surrounding the microsporogenous cells in tobacco. As a result, the microspores had an abnormally thin cell wall that lacked sculpturing and exhibited male sterility. Goetz et al. [43] found that tissuespecific antisense repression of an extracellular invertase in tobacco could affect extracellular sucrose cleavage for supplying carbohydrates from phloem to pollen and cause male sterility as a result of the blocking of pollen formation. Ruiz and Daniell [148] integrated the phaA gene encoding $\beta$-ketothiolase into the chloroplast genome of tobacco. This enzyme is involved in the polyhydroxybutyrate (PHB) synthesis pathway, and the transgenic plants exhibited male sterility as a result of the accelerated development pattern of anthers, aberrant tissues, and collapsed pollen grains. Madhuri et al. [86] developed an approach of expressing cytotoxic harpin ${ }_{\text {Pss, }}$, an elicitor molecule of bacterial origin, in the tapetum of tobacco. Harpin ${ }_{\text {Pss }}$ induced a hypersensitive response (HR) in the tapetum and resulted in male sterility because of premature tapetal cell death. Sinha and Rajam [162] down-regulated the transcripts of S-adenosylmethionine decarboxylase (SAMDC), a key gene involved in polyamine biosynthesis, in tapetal tissue of tomato (Solanum lycopersicum Mill. cv. Pusa Ruby) using RNA interference (RNAi) silencing and obtained RNAi tomato plants with sterile pollen.

Complete sterility is accomplished when both the male and female floral organs (stamens and carpels) are ablated. Liu and Liu [77] isolated the enhancer element of Arabidopsis AGAMOUS $(A G)$ that drives gene expression specifically in stamens and carpels and fused it with a minimal $35 \mathrm{~S}$ promoter fragment to create a tissue-specific promoter. By fusing this promoter with the Diphtheria toxin A (DT$A)$ gene coding for a ribosome-inactivating protein or the Barnase gene coding for an extracellular ribonuclease, high percentages of ablation of stamens and carpels were achieved in transgenic Arabidopsis thaliana plants, and complete sterility was obtained. Yang et al. [189] used the same type of chimeric promoters in which petunia (Petunia hybrid cv. V26) $A G$ second intron-enhancer fragment was fused to $35 \mathrm{~S}$ promoter and tested its application in tobacco. The expressions of the $\beta$-glucuronidase gene $(G U S)$ and $D T-A$ driven by the chimeric promoter were also found to be highly specific in the floral organs, and this method was very effective in engineering complete sterility. Another similar example was reported by Liu et al. [80] who fused the pollen-specific LAT52 and forward-oriented carpelspecific $A G L 5$ enhancers to a stigma-specific $S L G$ promoter and used these chimeric promoters to drive the expression of the $D T-A$ gene in carpels and pollen tissue for gene containment.

Similarly, for seed sterility, seed tissues are destroyed by introducing some type of cytotoxic protein under the 
control of certain inducing mechanisms. Schernthaner et al. [154] developed a repressible seed-lethal (SL) system in which gene 1, Agrobacterium gene for tryptophan-2monooxygenase (iaaM) and gene 2, Agrobacterium gene for indole-3-acetamide hydrolase $(\mathrm{ia} a H)$ were transferred into tobacco plants. Coexpression of gene 1 and gene 2 led to overproduction of indole-3-acetic acid (IAA) in the seed and consequently caused inhibition of seed germination. However, gene 1 was controlled by the seed-specific phaseolin promoter containing a binding site for the Escherichia coli TET repressor (R). When the transgenic plants containing the SL construct were crossed with the R lines, the expression of SL was repressed in F1 plants which allowed for normal seed formation and germination. But, once the SL lines crossed with wild-type or close relatives in which there was no tet $\mathrm{R}$ gene, the genes 1 and 2 on the SL construct would be expressed and cause seed lethality.

\section{Transgene Mitigation}

Transgene mitigation (TM) is an approach mainly developed for crop species to prevent gene flow to weeds. It takes advantage of the difference of characteristics between crops and weeds. Basically, the gene of interest is coupled in tandem with a mitigating gene that would be deleterious to weeds when it is integrated into the weeds' genome. Such traits include seed dormancy, seed ripening, and seed shattering. This harmful gene and other transgenes on the construct are considered to be tightly linked so that there is no segregation between them. This method requires a full understanding of the key genes involved in those processes, and it only protects weeds from being contaminated by transgenes, but offers no protection on other crop species or their relatives [2, 24]. Al-Ahmad et al. [2] transferred a dominant $\operatorname{ahas}^{R}$ gene (acetohydroxy acid synthase) conferring herbicide resistance in tandem with the semi-dominant mitigator dwarfing $\Delta g a i$ gene (gibberellic acidinsensitive) into tobacco. The crop-weed hybrids were suppressed when competing with wild-type weeds and had very low reproductive fitness, which ensured very low frequency of gene release. Al-Ahmad et al. [3] tested the same construct on transgenic oilseed rape plants because they were volunteer weeds in following crops and could contaminate crop yield. When grown as a crop, the TM dwarf B. napus plants had enhanced yield, but they could be eliminated when competing with non-transgenic cohorts because of their low reproductive fitness in competition with non-transgenic tall cohorts. Lin et al. [76] also used this technology to couple the herbicide resistance gene (glyphosate) and herbicide-sensitive gene (an RNAi cassette that suppresses the expression of the bentazon detoxification enzyme $C Y P 81 A 6)$ in a tandem construct to mitigate gene flow in rice (Oryza sativa L. ssp. japonica), and they could be selectively eliminated at $100 \%$ by bentazon. Kuparinen and Schurr [69] assessed the risk of gene flow from GM trees with mitigation transgenes. They concluded that to reduce the risk of the break-up between primary and mitigation transgenes, mitigation and primary transgenes need to be tightly linked and various factors including genetics, local dynamics, and dispersal of GM and conventional varieties need to be considered for risk assessment and management of GM tree populations.

\section{Tissue-Specific Gene Excision}

This system involves the use of site-specific recombinase under the control of a chemically inducible or tissue-specific promoter [61]. For example, upon the activation of some chemical compound or floral promoter/seed-specific promoter, the recombinase, such as Cre, is expressed and excises the foreign gene located between two recombinase sites (loxP in this case) in the entire plant, pollen, seeds, or the food portion. This gene-deletion technology was often used to remove marker genes by mating with recombinaseexpressing plants or co-transforming with recombinaseexpressing constructs. However, the removal may not be complete because of the incomplete induction or excision, and the recombinase recognition sites flanking the genes would also be left in the genome [24]. Furthermore, the transgene product may be degraded slowly and remain in the plant even after the excision of transgenes. Therefore, this technology needs to be optimized [61]. Luo et al. [85] examined the efficiency of loxP-FRT fusion sequence as the recombinase recognition sites, and found that this fusion sequence together with the recombinase FLP or CRE showed higher average excision efficiency in pollen or seed than the phage CRE/loxP or yeast FLP/FRT system with many transgenic events being $100 \%$ efficient. Moon et al. [102] believed that removal of transgenes from pollen by the site-specific recombinase system was the optimal solution for gene containment compared to male sterility and TM because it was more efficient, reliable, and applicable. They transferred a transgene excision vector containing a codon-optimized serine resolvase $\mathrm{CinH}$ recombinase $(\mathrm{CinH})$ under the control of a pollen-specific LAT52 promoter from tomato into tobacco [103]. The entire transgene cassette was flanked by the two recognition sites $(R S 2)$, and an enhanced green fluorescent protein gene $(e G F P)$ was also driven by LAT52 promoter as an indicator of transgene excision. Their results demonstrated that the CinH-RS2 recombination system was very effective in transgene excision. Petolino et al. [127] used another system, zinc finger nuclease $(\mathrm{ZFN})$ for transgene deletion. The tobacco plants were transformed with a GUS reporter gene flanked by $\mathrm{ZFN}$ cleavage sites, and a second 
tobacco line was transformed with a ZFN gene. When crosses were made between these two homozygous lines, about $35 \%$ GUS-negative plants were observed among the hybrids with one particular cross. Although the efficiency was not as high as the recombinase system, it provided a new strategy for gene excision.

\section{Interference with the Floral-Related Genes}

In addition to the application of floral tissue-specific promoters of the floral genes for tissue ablation, direct manipulation of the expression of genes that control initiation and development of inflorescence and floral organs is another approach to achieve gene containment. In the ABCDE model of flower organ identity, the genes that regulate the development of floral tissues are divided into classes of A, B, C, D, and E based on the regions of floral meristem where they are expressed and their functions in specifying the floral organ identity [171]. Most of the floral organ identity genes belong to the MADS family which share highly conserved regions of about 180 base pairs encoding the DNA-binding domain (MADS-box) [172]. The classic MADS-box floral homeotic proteins in Arabidopsis include APETALA1 (AP1), AP3, PISTILLATA (PI), AG, and SEPALLATA3 (SEP3) (Table 1). Based on the ABCDE model, RNAi silencing of class B or class $C$ floral organ identity genes would cause abnormal development of stamens or carpels and eventually lead to the sterile phenotype. Yoshida et al. [193] identified a mutant of rice which had a missense mutation in the class B MADS-box gene SUPERWOMAN1 (SPWI) (AP3 homo$\log )$. It led to cleistogamy because of altered lodicule identity and cleistogame is an efficient approach to prevent pollen dispersal in GM crops. Liu et al. [82] cloned and characterized an $A G$ homolog from black cherry and made an RNAi construct with a partial $P S A G$ gene for reproductive sterility by RNAi silencing of $P s A G$. Mitsuda et al. [100] used Chimeric Repressor gene-Silencing Technology (CRES-T) in which four transcription factors AP3, AG, LEAFY (LFY), and AtMYB26 were fused with the modified EAR-like motif repression domain (SRDX), respectively, and transferred separately into Arabidopsis and rice. The male and female sterile transgenic plants were obtained at high frequencies. Sato et al. [152] also used this technology by fusing SRDX with the coding regions of rice $A P 3$ ortholog SPW1 and rice $A G$ ortholog OsMADS58, respectively, and introduced the chimeric repressor SPWISRDX and OSMADS58SRDX into tall fescue (Festuca arundinacea Schreb.). The transgenic tall fescue showed both male-sterility and cleistogamous phenotype in which the morphology of the lodicules were abnormal and led to closed florets, suggesting the potential use of this technology in gene containment. Interestingly, accumulation of AP2 could also result in transgene containment through production of the cleistogamous phenotype. Nair et al. [107] reported that cleistogamous flowering in barley was caused by a single nucleotide change at the miR172 targeting site in the $H v A P 2$ gene (an ortholog of Arabidopsis thaliana AP2) that suppressed microRNA-guided $H v A P 2$ mRNA cleavage within the lodicule primordial, up-regulated B-class genes, and led to smaller lodicule, indicating complex interactions and regulations between the floral organ identity genes.

Floral meristem identity genes include $A P 1, L F Y$, and CAULIFLOWER (CAL), whereas shoot meristem identity genes include TERMINAL FLOWER 1 (TFL1), TERMINAL FLOWER 2 (TFL2), and WUSCHEL (WUS) (Table 1). Overexpressions of $L F Y$ and FLOWERING LOCUS T (FT) were used to produce early flowering poplar (Populus tremula $\mathrm{L}$.) so that a faster evaluation of gene containment could be made on various containment strategies in transgenic trees [55]. The impact of $A P 1$ overexpression seemed more complicated than that of other genes as shown by Duan et al. [31] who transformed kumquat (Fortunella crassifolia Swingle.) with Arabidopsis API. Both earlyflowering and late-flowering were observed among transgenic kumquat plants, which may be a result of the interaction of exogenous $A P 1$ and endogenous flowering genes, including $L F Y, F T$, and $T F L 1$. An et al. [6] studied PtLFY, a $L F Y$ homolog in Populus tomentosa and successfully blocked flowering by transferring an inverted repeat $P t L F Y$ fragment (PtLFY-IR) which induced post-transcriptional gene silencing (PTGS). Zhang et al. [196] found an Arabidopsis gain-of-function mutant woxl-D in which WOXI (WUSCHEL HOMEOBOX 1) was overexpressed. The mutant plant showed a dwarfed phenotype, a smaller shoot apex, anther dehiscence failure, and male sterility. However, WUS and WUS-like WOX genes play an essential role in determining stem cell fate in the shoot meristem, and the interference of these genes would have a great impact on plant growth and development. So these are not suitable for gene manipulation.

Another group of proteins such as CONSTANS (CO), FT, FLOWERING LOCUS C (FLC), SUPPRESSOR OF OVEREXPRESSION OF CO 1 (SOC1), FD (a bZIP transcription factor), and SHORT VEGETATIVE PHASE (SVP) are involved in the regulation of flowering time (Table 1). CO was considered to promote flowering in long days. However, González-Schain and Suárez-López [45] reported that potato (Solanum tuberosum ssp. andigena) plants constitutively expressing Arabidopsis $C O$ flowered late under all photoperiodic conditions. They proposed that it was caused by its interference with a potato $\mathrm{CON}$ STANS-LIKE (COL) protein that would presumably induce flowering, and previous studies showed that $C O L$ genes could have either a positive or negative effect on 
Table 1 Major genes involved in the initiation and development of flowering in Arabidopsis

\begin{tabular}{|c|c|c|c|c|}
\hline Gene name & Gene product & Location & Functions & References \\
\hline \multicolumn{5}{|c|}{ Floral organ identity genes } \\
\hline APETALA1 (AP1) & $\begin{array}{l}\text { MADS-box transcription } \\
\text { factor }\end{array}$ & Young flower primordia & Sepal and petal development & Mandel et al. [88] \\
\hline APETALA3 (AP3) & $\begin{array}{l}\text { MADS-box transcription } \\
\text { factor }\end{array}$ & Petals and stamens & Petal and stamen development & Jack et al. [59] \\
\hline PISTILLATA $(P I)$ & $\begin{array}{l}\text { MADS-box transcription } \\
\text { factor }\end{array}$ & Petals and stamens & Acts together with $A P 3$ & $\begin{array}{l}\text { Goto and } \\
\text { Meyerowitz [46] }\end{array}$ \\
\hline$A G A M O U S(A G)$ & $\begin{array}{l}\text { MADS-box transcription } \\
\text { factor }\end{array}$ & Stamens and carpels & $\begin{array}{l}\text { Stamen and carpel } \\
\text { development }\end{array}$ & $\begin{array}{l}\text { Yanofsky et al. } \\
\text { [190] }\end{array}$ \\
\hline SEPALLATA3(SEP3) & $\begin{array}{l}\text { MADS-box transcription } \\
\text { factor }\end{array}$ & Petals, stamens, and carpels & $\begin{array}{l}\text { Interacts with } A P 1 \text { to promote } \\
\text { normal flower development }\end{array}$ & Pelaz et al. [119] \\
\hline \multicolumn{5}{|c|}{ Floral meristem identity genes } \\
\hline APETALA1 (AP1) & $\begin{array}{l}\text { MADS-box transcription } \\
\text { factor }\end{array}$ & Young flower primordia & $\begin{array}{l}\text { Flowering initiation and up- } \\
\text { regulation of } L F Y \text { expression } \\
\text { level }\end{array}$ & Mandel et al. [88] \\
\hline$L E A F Y(L F Y)$ & Transcription factor & Young flower primordia & $\begin{array}{l}\text { Promotes the transition from } \\
\text { inflorescence to floral } \\
\text { meristem and controls floral } \\
\text { meristem identity }\end{array}$ & Weigel et al. [185] \\
\hline $\begin{array}{l}\text { CAULIFLOWER } \\
(C A L)\end{array}$ & $\begin{array}{l}\text { MADS-box transcription } \\
\text { factor }\end{array}$ & Young flower primordia & $\begin{array}{l}\text { Closely related to } A P 1 \text {; } \\
\text { flowering initiation and up- } \\
\text { regulation of } L F Y \text { expression } \\
\text { level }\end{array}$ & Kempin et al. [62] \\
\hline \multicolumn{5}{|c|}{ Shoot meristem identity genes } \\
\hline $\begin{array}{l}\text { TERMINAL FLOWER } \\
\quad 1 \text { (TFL1) }\end{array}$ & $\begin{array}{l}\text { Phosphatidylethanolamine } \\
\text { binding proteins (PEBP) } \\
\text { gene family; transcription } \\
\text { factor }\end{array}$ & $\begin{array}{l}\text { Center of the inflorescence } \\
\text { apex }\end{array}$ & $\begin{array}{l}\text { Regulating vegetative to } \\
\text { reproductive phase transition }\end{array}$ & $\begin{array}{l}\text { Ohshima et al. [114] } \\
\text { and Ratcliffe et al. } \\
\text { [143] }\end{array}$ \\
\hline $\begin{array}{l}\text { TERMINAL FLOWER } \\
2 \text { (TFL2) }\end{array}$ & $\begin{array}{l}\text { A heterochromatin protein } \\
\text { 1-like protein; } \\
\text { transcription factor }\end{array}$ & $\begin{array}{l}\text { Proliferating cells in the } \\
\text { meristematic tissues of } \\
\text { vegetative, inflorescence, } \\
\text { and floral organs }\end{array}$ & $\begin{array}{l}\text { Repressing } F T \text { and delaying } \\
\text { flowering time }\end{array}$ & Kotake et al. [65] \\
\hline WUSCHEL (WUS) & $\begin{array}{l}\text { Homeobox }(\mathrm{HB}) \text { gene } \\
\text { family; transcription factor }\end{array}$ & Shoot meristem precursor cells & $\begin{array}{l}\text { Determining the stem cell fate } \\
\text { in shoot meristem }\end{array}$ & Mayer et al. [95] \\
\hline \multicolumn{5}{|l|}{ Flowering time genes } \\
\hline CONSTANS $(C O)$ & $\begin{array}{l}\text { Zinc finger transcription } \\
\text { factor }\end{array}$ & Leaf phloem tissues & $\begin{array}{l}\text { Promotes flowering; links the } \\
\text { circadian clock and } \\
\text { flowering time }\end{array}$ & $\begin{array}{l}\text { Putterill et al. [139], } \\
\text { Suárez-López } \\
\text { et al. [164], and } \\
\text { An et al. [5] }\end{array}$ \\
\hline $\begin{array}{l}\text { FLOWERING LOCUS } \\
\quad T(F T)\end{array}$ & $\begin{array}{l}\text { The PEBP gene family; } \\
\text { transcription factor }\end{array}$ & $\begin{array}{l}\text { All tissues in seedlings and } \\
\text { mature plants }\end{array}$ & $\begin{array}{l}\text { Regulated by } C O \text { and can } \\
\text { promote flowering together } \\
\text { with } L F Y \text {; antagonistic } \\
\text { function with } T F L 1\end{array}$ & $\begin{array}{l}\text { Kobayashi et al. } \\
\text { [64] }\end{array}$ \\
\hline $\begin{array}{l}\text { FLOWERING LOCUS } \\
\quad C(F L C)\end{array}$ & MADS-box transcription & & A repressor of flowering & $\begin{array}{l}\text { Michaels and } \\
\text { Amasino [97] }\end{array}$ \\
\hline $\begin{array}{l}\text { SUPPRESSOR OF } \\
\text { OVEREXPRESSION } \\
\text { OF CO } 1 \text { (SOC1) }\end{array}$ & $\begin{array}{l}\text { MADS-box transcription } \\
\text { factor }\end{array}$ & Shoot apex and leaves & $\begin{array}{l}\text { Activated by } C O \text { through } F T \text { to } \\
\text { promote flowering }\end{array}$ & Lee et al. [72] \\
\hline$F D$ & A bZIP transcription factor & Shoot apex & $\begin{array}{l}\text { Interacts with } F T \text { to promote } \\
\text { floral transition and to } \\
\text { initiate floral development }\end{array}$ & Abe et al. [1] \\
\hline $\begin{array}{l}\text { SHORT VEGETATIVE } \\
\quad \text { PHASE }(S V P)\end{array}$ & $\begin{array}{l}\text { MADS-box transcription } \\
\text { factor }\end{array}$ & $\begin{array}{l}\text { Vegetative tissues and floral } \\
\text { primordia }\end{array}$ & $\begin{array}{l}\text { Prolongs the vegetative phase } \\
\text { and represses the floral } \\
\text { transition }\end{array}$ & Hartmann et al. [53] \\
\hline
\end{tabular}


flowering. Yeoh et al. [192] developed a controlledinducible flowering system in Arabidopsis for flowering control using a novel combination of endogenous and heterologous $F T$ genes. First, they silenced $F T$ with an artificial microRNA directed at $F T(a m i R-F T)$ and obtained plants with strongly delayed flowering. Then, they expressed a heterologous $F T$ gene ( $F T a 1$ ) from Medicago truncatula under an alcohol-inducible promoter. Since FTal would not be targeted by the amiR-FT, exposure to ethanol could induce flowering whenever it was needed. Xing et al. [187] overexpressed an FT homolog from Prunus mume in Rosa rugosa 'Bao White' and observed early flowering and increased expression level of APl and SOCl. Tadege et al. [168] ectopically expressed the Arabidopsis FLC in rice and obtained delayed flowering in transgenic plants which was the result of inhibition of SOCl expression by FLC. Searle et al. [157] also reported the repression of FLC on SOC1, FD, and FT in Arabidopsis and the extreme delay in flowering caused by $F L C$. These results suggested that manipulation of FLC and SOC1 expression may be able to delay flowering dramatically. Ectopic expression of SVP from trifoliate orange (Poncirus trifoliate L. Raf.) in tobacco inhibited early transition of the coflorescence and prolonged coflorescence development [74]. Overexpression of SVP from Eucalyptus grandis and Chinese cabbage plants (Brassica campestris L. ssp. pekinensis) were able to cause late flowering and floral defects in Arabidopsis [17, 73], indicating the potential use of such overexpression for genetic manipulation of flowering time.

\section{TERMINAL FLOWER 1}

TFL1 gene functions upstream from the organ identity genes. It was first cloned from Arabidopsis [114] and has been intensively studied in many plant species because of its important role in regulating the vegetative to reproductive phase transition.

TFL1 homologs have been cloned and characterized in Arabidopsis, soybean (Glycine max L. Merr.), cotton, black cherry, and many fruit tree species including apple (Malus $\mathrm{x}$ domestica Borkh.), apricot (Prunus armeniaca L.), and peach (Prunus persica L. Batsch) [7, 75, 81, 114, 178]. It delays flowering and suppresses the development of the inflorescence meristem by repressing the genes activated by $F T$ at the transcriptional level [51]. Its level is also regulated by downstream genes in the flowering pathway, such as $A P 1$ that belongs to class A genes in the ABCDE model. Like $L F Y$ and $F T, T F L 1$ was often used to promote flowering and to reduce generation time in trees [38, 67, 167]. Transgenic rice overexpressing $R C N 1$ or $R C N 2$, rice TFL1/CEN homologs showed a delay of transition to the reproductive phase and altered panicle structure [108].
TFL1 from apple and wine grape (Vitis vinifera L.) was introduced into Arabidopsis and was able to cause significantly delayed flowering [16, 66]. Danilevskaya et al. [25] generated transgenic maize (Zea mays L.) overexpressing its own TFL1-like genes, and those transgenic plants exhibited delayed flowering and altered inflorescence architecture. A TFL1 homolog from black cherry has been cloned and characterized [178]. It has a single copy in the black cherry genome. The phylogenetic analysis of the amino acid sequences showed high identity of PSTFL1 to TFL1 orthologs of other Prunus species. Both the wild-type (Col-0) and the mutant tfl-11 Arabidopsis thaliana plants that overexpressed PSTFL1 showed significantly delayed flowering and abnormal floral structure with flower-toshoot conversions. Therefore, TFL1 could be a potential gene for flowering control in transgenic black cherry.

Various strategies to manipulate flowering through genetic engineering have been developed and widely used in different species. Except for TM and chloroplast transformation, the methods basically target male or female floral organs or seed by expressing certain types of enzymes or toxins to damage the tissues, overexpressing, or repressing the important genes in the network, or by removing the transgenes in these tissues. Among these approaches, the methods that could be applied to black cherry for flowering control would be to destroy or inhibit the development of floral organs or seed by expressing certain enzymes or toxins or by regulating the key genes, as there is more information available in related Prunus species [20, 150]. The repression of $A G$ or overexpression of TFL1 in black cherry for reproductive sterility has been investigated [79, 180]. Further efforts are encouraged to achieve complete and stable reproductive sterility.

\section{Cyanogenesis}

Cyanogenesis is considered to be an ancient plant defense system that exists in more than 2,500 plant species [101]. Black cherry is also one of the cyanogenic plant species. Upon tissue disruption caused by chewing insects, mix of the cyanogenic glycosides and compartmentalized enzymes catalyzing their degradation leads to liberation of the toxic gas, hydrogen cyanide (HCN). Metabolic pathway of cyanogenesis involves two sequential steps of reaction: the conversion of cyanogenic glycoside to $\alpha$-hydroxynitrile catalyzed by $\beta$-glucosidase, and the conversion of $\alpha$-hydroxynitrile to $\mathrm{HCN}$ catalyzed by hydroxynitrile lyase [159]. In leaves and vascular tissues of black cherry, the two corresponding enzymes involved in these reactions are prunasin hydrolase (PH) and mandelonitrile lyase (MDL), respectively. Both genes encoding the $\mathrm{PH}$ and MDL enzymes have been cloned and characterized by Zheng and 
Poulton [197] and Cheng and Poulton [21], respectively, and both of them have multiple isoforms that have been well characterized [58, 198]. PH is confined to the vacuoles of phloem parenchyma cells, whereas MDL was observed in phloem parenchyma vacuoles in different cells than those containing PH [165]. The first effort to use this natural defense mechanism through metabolic engineering was conducted by Tattersall et al. [170] who transferred the entire biosynthetic pathway of the cyanogenic glucoside, dhurrin, from Sorghum bicolor to Arabidopsis and successfully conferred resistance to the flea beetle (Phyllotreta nemorum L.). Selmar et al. [159] believed that the effective defense depends not only on cyanide potential ( $\mathrm{HCNp}$; concentration of cyanogenic precursors), but on the rapid release of $\mathrm{HCN}$ ( $\mathrm{HCNc}$; release rate of cyanide) as well [10]. The latter could be achieved by increasing the enzymes, $\beta$-glucosidase and hydroxynitrile lyase (HNL), involved in cyanogenesis. Siritunga et al. [163] overexpressed $H N L$ in cassava (Manihot esculenta) and proved that the elevated level of HNL accelerated cyanogenesis. Narayan et al. [109] also overexpressed $H N L$ specifically in roots of cassava, and the transgenic plants had largely reduced levels of cyanogenic glucosides and cyanide after food processing, making it a safer food product. Therefore, it is promising to increase the levels of the PH and MDL enzymes in black cherry for rapid cyanogenesis and successful protection against herbivores. However, Ballhorn et al. [10] pointed out that only the generalist herbivores could be effectively repelled by high $\mathrm{HCNc}$, while the specialist herbivores chose to consume host plants that had lower HCNp. Hence, it is difficult to predict whether transgenic black cherry plants with increased HCNp would be effective in repelling its major insect pests before feeding trials.

Another major concern of this strategy is whether those insect pests that cause gummosis in black cherry are susceptible to cyanide poisoning. This is because some adapted insects are found to be able to suppress $\mathrm{HCN}$ production and take in the cyanogenic glucosides as a valuable nitrogen source [4]. Fitzgerald [36] reported that the larvae of the fall webworm, Hyphantria cunea Drury, were able to efficiently inhibit the conversion of the cyanogens to cyanide sufficiently in its alkaline foregut environment. The eastern tent caterpillar, Malacosoma americanum Fab., was found to be immune to ingested or inhaled cyanide generated from black cherry leaves by detoxification with an unknown mechanism [37]. Furthermore, some insect species could synthesize cyanogenic glucosides in vivo for their own defense, which include the members in Coleoptera (beetles), Heteroptera (true bugs), and Lepidoptera (butterflies and moths) [194]. However, the major chewing insects of black cherry, peach bark beetles (Coleoptera: Scolytidae), the lesser and greater peachtree borers (Lepidoptera: Sesiidae), and Agromyzid cambium miner (Diptera: Agromyzidae) have not been reported to be resistant to cyanide. On the other hand, there is supporting evidence that the larvae of the lesser peachtree borers do not have the ability to detoxify cyanide produced from peach tree rootstocks [144]. In addition, Ballhorn et al. [9] reached the conclusion that cyanidecontaining precursors could still have negative long-term effects even on specialist herbivores that are adapted to feed on cyanogenic plants based on their study with the Mexican bean beetle (Coleoptera: Coccinellidae: Epilachna varivestis Mulsant) on lima bean. Therefore, this strategy may effectively enhance the host plant resistance of black cherry to its pests. Attempts have been made by Wang and Pijut [180] to overexpress PH3 or MDLA from black cherry in the same species for insect resistance. The transgenes derived from black cherry were used, as this protocol would be more acceptable [142], but transgene silencing was observed possibly because of tight posttranscriptional regulation of the two genes. Therefore, the orthologous genes derived from other Prunus species may be the next step to test.

\section{Micropropagation, Adventitious Shoot Regeneration, and Rooting of Prunus Species}

The Prunus genus includes about 430 species of trees and shrubs throughout temperate regions [177]. Many of them are of high economic value and are cultivated globally for fruit, such as apricot, sweet cherry, plum, peach, and almond. Therefore, large research efforts have been made on these species. As one of the features of tissue culture is that it is highly genotype dependent and cultivar specific, a great number of protocols were developed for different cultivars or genotypes. Here we focus on six species of Prunus, and first discuss the major research progress in micropropagation and adventitious shoot regeneration as it is the foundation for genetic engineering and modern biotechnology, followed by the review of Agrobacteriummediated transformation systems for each of the six species.

\section{Prunus serotina Ehrh.}

Tricoli et al. [175] first started in vitro micropropagation and rooting of mature black cherry trees using twigs with winter buds cultured on Murashige and Skoog (MS) medium [105] supplemented with $4.44 \mu \mathrm{M}$ benzyladenine (BA), $0.49 \mu \mathrm{M}$ indole-3-butyric acid (IBA), $0.29 \mu \mathrm{M}$ gibberellic acid $\left(\mathrm{GA}_{3}\right)$, and $2 \%$ sucrose. Root formation was induced on MS medium containing $4.9 \mu \mathrm{M}$ IBA under continuous dark treatment compared to a $16-\mathrm{h}$ photoperiod. 
Drew et al. [29] further tested the acclimatization of micropropagated black cherry plantlets by comparing their whole plantlet growth rate and water relations with those of half-sib seedlings. These results indicated that the micropropagated plantlets had lower growth rates, less leaf area, and lower relative root growth rate than seedlings after 8 weeks of acclimatization. But, there were no significant differences in total weight between the two by the third growing season. The first adventitious shoot regeneration protocol using leaves of in vitro black cherry cultures was established by Hammatt and Grant [50] with the aim of preparing for Agrobacterium-mediated transformation. Woody plant medium (WPM; [83] supplemented with $4.4 \mu \mathrm{M}$ thidiazuron (TDZ) and $0.54 \mu \mathrm{M}$ naphthaleneacetic acid (NAA) was found to be better in shoot regeneration of five genotypes (Seedling A, PSB, 2322, 2339, and Pavia E) of black cherry than the modified Driver and Kuniyuki [30] walnut (DKW) medium and BA. Espinosa et al. [34] tested the effects of various combinations of BA or TDZ with NAA in WPM and the effect of the length of dark treatment on the regeneration rates of genotypes $\mathrm{A}, \mathrm{D}$, and $\mathrm{F}$. TDZ was again found to be better than BA in shoot regeneration of black cherry. Adventitious shoots and nodal-explantderived stock cultures were both able to root on MS medium containing $2.5 \mu \mathrm{M}$ IBA, but adventitious shoots had a lower rooting rate $(27 \%)$ and required longer dark treatment compared to nodal-explant-derived stock cultures. Liu and Pijut [78] also developed a shoot regeneration system for a juvenile (F) and two mature (\#3 and \#4) genotypes of black cherry using WPM containing 4.54 or $9.08 \mu \mathrm{M}$ TDZ, $1.07 \mu \mathrm{M}$ NAA, and 60 or $80 \mu \mathrm{M}$ silver thiosulfate (STS) with a 3-week dark treatment. Roots were induced by a $2.5 \mathrm{mM}$ IBA dip for 3 min followed by 4 days of dark treatment before being exposed to light for root development.

\section{Prunus armeniaca $\mathrm{L}$.}

Since apricot is a very important stone fruit tree species, a number of studies have been conducted on the tissue culture of apricot to facilitate its genetic engineering for fruit quality and disease resistance [183, 184]. Pérez-Tornero et al. [124] established in vitro apricot cultivars from meristem tips and micropropagated in vitro shoots on modified Quoirin and Lepoivre (QL) medium [140] with $0.05 \mu \mathrm{M}$ IBA, BA, and GA with the concentrations depending on each genotype. Later they investigated the impact of different nutrient media and BA concentration on the micropropagation and rooting of several apricot cultivars and found that QL medium and double-strength WPM macronutrients without $\mathrm{K}_{2} \mathrm{SO}_{4}$ were the best among the six media tested. The optimal BA concentration was between 1.78 and $3.11 \mu \mathrm{M}$ [123]. Rooting of apricot shoots required a dark treatment. Shoots rooted well on the rooting medium containing 1/3 macronutrients and half-strength micronutrients, organics, vitamins, 9.8, 19.6, or $29.4 \mu \mathrm{M}$ IBA, 2.69 or $5.37 \mu \mathrm{M}$ NAA, $2 \%$ sucrose, and $0.5 \%$ agar. Dipping the shoot tips in solutions of 22.2 or $44.4 \mu \mathrm{M}$ BA prior to transfer to rooting medium solved the problem of apical necrosis after rooting. Shoot regeneration through adventitious induction in apricot has been achieved from juvenile explants or endosperm by many research groups. Lane and Cossio [70] induced adventitious shoots from cotyledons of immature apricot embryos using MS medium supplemented with $5 \mu \mathrm{M}$ BA and $1 \mu \mathrm{M}$ 2,4-dichlorophenoxyacetic acid (2,4-D) and obtained $80 \%$ regeneration. Roots were initiated in half-strength MS medium with $5 \mu \mathrm{M}$ NAA for 4 weeks followed by transfer to a plant growth regulator-free medium for 3 weeks. Pieterse [136] regenerated apricot shoots from immature embryos using two different methods, but the regeneration rate was low. The first method involved using MS medium with $4.5 \mu \mathrm{M}$ 2,4$\mathrm{D}$ and $0.44 \mu \mathrm{M}$ BA for callus initiation, and regenerating shoots from the callus on MS medium with $1 \mu \mathrm{M}$ 2,4-D and $4.4 \mu \mathrm{M}$ BA. The second protocol was to regenerate adventitious buds directly from the cotyledons on MS medium containing $1 \mu \mathrm{M} 2,4-\mathrm{D}$ and $4.4 \mu \mathrm{M}$ BA. The shoots developed roots spontaneously on MS medium with $4.4 \mu \mathrm{M} \mathrm{BA}$ and $0.49 \mu \mathrm{M}$ IBA. Goffreda et al. [44] obtained shoot regeneration from immature embryos or cotyledons of apricot on MS medium with $5 \mu \mathrm{M}$ IBA. Rooting was induced after the cultures were placed in darkness for approximately 2 weeks on WPM with $10 \mu \mathrm{M}$ IBA. Escalettes and Dosba [33] published the first series of protocols of in vitro adventitious shoot regeneration from leaves of mature apricot explants. They used QL or halfstrength MS medium supplemented with silver nitrate, TDZ alone or in combination with NAA. Pérez-Tornero et al. [125] evaluated several factors that affect regeneration percentage of apricot and established a more reproducible and efficient protocol which consisted of QL basal medium supplemented with $9 \mu \mathrm{M} \mathrm{TDZ}, 2.7 \mu \mathrm{M}$ NAA, $3 \%$ sucrose, and $0.6 \%$ agar. The regeneration percentage reached $24.3 \%$, and they suggested using young expanding leaves with the adaxial side touching the culture medium and maintaining them for 2 or 3 weeks in darkness. Wang et al. [182] developed a protocol of adventitious shoot regeneration from hypocotyl slices of mature apricot seeds and achieved approximately $30 \%$ regeneration rate for all three cultivars tested: 'Canino', 'Moniquí', and 'Dorada'. The shoot regeneration medium consisted of 3/4-strength MS salts supplemented with full-strength MS vitamins, $7 \mu \mathrm{M}$ TDZ, $0.25 \mu \mathrm{M}$ IBA, $2 \%$ sucrose, and $0.7 \%$ purified agar. Later, they established a direct, versatile, and efficient shoot regeneration protocol from the proximal zone of mature apricot cotyledons [183]. The 
optimal shoot regeneration medium was QL basal medium supplemented with TDZ (4 or $8 \mu \mathrm{M})$ and $0.25 \mu \mathrm{M}$ IBA in combination with 2 weeks of dark incubation.

\section{Prunus avium L.}

Hammatt and Grant [49] found that micropropagated shoots of British wild cherry produced on MS medium with $1 \mathrm{mM}$ phloroglucinol (PG), $0.49 \mu \mathrm{M}$ IBA, $4.4 \mu \mathrm{M}$ BA, and $0.29 \mu \mathrm{M} \mathrm{GA}_{3}$ were easier to root on a rooting medium supplemented with $1 \mathrm{mM}$ PG. Muna et al. [104] also used MS medium with $4.44 \mu \mathrm{M}$ BA and $0.49 \mu \mathrm{M}$ IBA for in vitro micropropagation of the semi-dwarfing sweet cherry, and roots were induced best in liquid half-strength MS medium containing $2.45 \mu \mathrm{M}$ IBA. Durkovič [32] reported a rapid micropropagation procedure of mature wild cherry. The highest multiplication rate was obtained using WPM containing $2.1 \mu \mathrm{M}$ BA and $0.23 \mu \mathrm{M}$ TDZ. Shoots $(73 \%)$ rooted on half-strength WPM supplemented with $1.4 \mu \mathrm{M}$ IBA. Shatnawi et al. [160] developed an in vitro propagation protocol for sweet cherry using MS medium supplemented with $4.44 \mu \mathrm{M}$ BA. To optimize the micropropagation of sweet cherry cv. Lapins, Ružić and Vujović [149] tested the effects of four types of cytokinins at different levels on various physiological parameters. Their results showed that BA was the best for multiplication, but the medium containing kinetin or $6-(\gamma, \gamma$-Dimethylallylamino) purine (2iP) could induce rooting while stimulating shoot growth. Sedlak and Paprstein [158] also made some efforts to improve the in vitro shoot proliferation of sweet cherry cv. Karesova and Rivan. However, they were only able to promote proliferation in Rivan with MS medium containing $8.88 \mu \mathrm{M} \mathrm{BA}$, and the proliferation rate was still not satisfactory for large-scale production. Scaltsoyiannes et al. [153] reported a micropropagation protocol for mature wild cherry that consisted of a modified MS medium supplemented with $4.44 \mu \mathrm{M} \mathrm{BA}$ and $0.05 \mu \mathrm{M}$ IBA. Rooting percentage reached $100 \%$ on $1 / 5$ MS medium supplemented with $9.8 \mu \mathrm{M}$ IBA and $2 \%$ sucrose. Hammatt and Grant [50] established a regeneration protocol for wild cherry using furled leaf explants with the midrib cut twice transversely. Relatively low regeneration percentage was obtained using WPM with $0.54 \mu \mathrm{M}$ NAA and $4.4 \mu \mathrm{M}$ TDZ. Regeneration was also achieved from unfurled leaves on WPM with 4.4 or $22.2 \mu \mathrm{M}$ TDZ. Later, they found that leaves of 3-5 $\mathrm{mm}$ in length formed most shoots and the surfactant Tween-20 at $10 \mathrm{mg} \mathrm{L}^{-1}$ increased the number of shoots per leaf and the number of positions per leaf that formed shoots [47]. Tang et al. [169] achieved shoot regeneration from leaves of four sweet cherry cultivars on WPM supplemented with $8.88 \mu \mathrm{M}$ BA and 2.3-4.6 $\mu \mathrm{M}$ NAA, and root formation on half-strength MS medium containing $9.8 \mu \mathrm{M}$ IBA or $10.8 \mu \mathrm{M}$ NAA.
Bhagwat and Lane [12] obtained regeneration percentages of 71.4 and $54 \%$ for sweet cherry cv. Lapins and Sweetheart, respectively, using whole-leaf explants wounded by transverse cuts along the midrib and incubated abaxial surface in contact with WPM supplemented with 2.27 or $4.54 \mu \mathrm{M}$ TDZ plus $0.27 \mu \mathrm{M}$ NAA. Matt and Jehle [94] compared adventitious shoot regeneration from leaves and internode sections of five sweet cherry cultivars. The regeneration efficiency was highly genotype specific, and generally the best regeneration medium was DKW:WPM (1:1) or QL basal medium containing TDZ and IBA. Regeneration from internode sections was found to be much more efficient than from leaves. Feeney et al. [35] reported a complete protocol of adventitious shoot regeneration of sweet cherry from four explant types which involved using MS medium with $3 \mu \mathrm{M}$ BA and $1 \mathrm{mM}$ PG as pretreatment, followed by half-strength MS medium with $3 \mu \mathrm{M}$ BA for callus formation, and WPM with $3 \mu \mathrm{M}$ BA for shoot induction. Canli and Tian [18] achieved shoot regeneration from stored mature cotyledons on medium containing QL basal salts, $2.5 \mu \mathrm{M}$ IBA, 3.6-7.2 $\mu \mathrm{M}$ TDZ, $2.5 \%$ sucrose, and vitamins combined with 10-day dark incubation.

\section{Prunus domestica $\mathrm{L}$.}

Baleriola-Lucas and Mullins [8] established a micropropagation protocol for two prune cultivars that consisted of MS medium with $4.44 \mu \mathrm{M}$ BA, $0.43 \mu \mathrm{M}$ IBA, and $1 \mathrm{mM}$ PG. Rooting was achieved on MS medium with $5.7 \mu \mathrm{M}$ IAA and $1 \mathrm{mM}$ PG. Vasar et al. [176] reported that in vitro shoots of plum on full-strength MS medium had darker green leaves than those on modified MS medium with lower nitrogen concentration. BA was found to be able to induce shoot proliferation, while shoots treated with $2 \mathrm{iP}$ could be acclimatized more easily. Nowak et al. [112] found that sucrose as a carbohydrate source was better for regeneration from leaf explants of 'Węgierka Zwykła' plum than glucose, and sucrose content higher than $5 \%$ led to a decrease in regeneration capacity. By sampling the sugar content in the medium, they found that sugar uptake in the dark period of regeneration was half or less than that in the second photoperiod conditions. Nowak et al. [113] reported that full- or half-strength MS medium with ammonium $\left(\mathrm{NH}^{4+}\right)$ and nitrate $\left(\mathrm{NO}^{3-}\right)$ ratios of $1: 2$ or $1: 4$ resulted in higher rates of regeneration from leaf explants of 'Weqgierka Zwykła' plum than the medium with an excess of ammonium versus nitrate ions. Tian et al. [173] studied 13 European plum varieties and found that hypocotyls from immature seeds had higher regeneration efficiency than those from mature seeds. Shoots were regenerated on MS medium containing $2.5 \mu \mathrm{M}$ IBA and $7.5 \mu \mathrm{M}$ TDZ. Half-strength MS medium with $5 \mu \mathrm{M}$ NAA 
and $0.01 \mu \mathrm{M}$ kinetin was better for root induction than the same basal medium containing $2.5 \mu \mathrm{M}$ IBA. Petri and Scorza [128] reported an adventitious shoot regeneration protocol of 'Improved French' plum from leaf explants. The shoot proliferation medium for the stock plants was found to be very important in shoot regeneration, and MS medium with $3 \mu \mathrm{M}$ BA and $0.25 \mu \mathrm{M}$ IBA was used for regeneration. Other factors, such as the concentration of TDZ in the regeneration medium, the duration of dark treatment, the gelling agent, and the level of STS were all optimized to obtain a regeneration rate of $65 \%$. Rooting rate was improved on full-strength MS medium containing $0.1 \mu \mathrm{M}$ kinetin and $5 \mu \mathrm{M}$ NAA, or half-strength $\mathrm{MS}$ medium containing $0.1 \mu \mathrm{M}$ kinetin, $5 \mu \mathrm{M}$ NAA, and $0.73 \mathrm{mM}$ PG. Yao et al. [191] found that WPM supplemented with $9.08 \mu \mathrm{M}$ TDZ and $0.9 \mu \mathrm{M}$ 2,4-D combined with 2 weeks in darkness was optimal for shoot regeneration from petioles of European plum 'Tardicots', and rooting rate reached $93.3 \%$ on MS medium with $4.9 \mu \mathrm{M}$ IBA after 7 days in the dark.

\section{Prunus mume Sieb. et Zucc.}

Harada and Murai [52] developed a shoot proliferation protocol for Japanese apricot consisting of WPM with $5 \mu \mathrm{M}$ BA, $3 \%$ glucose, and solidified with $0.5-0.7 \%$ agar. The rooting medium contained WPM supplemented with $1 \mu \mathrm{M}$ NAA, but the survival rate was very low after acclimatization (20-30\%). Ning et al. [111] obtained axillary shoot proliferation when nodal segments from seedlings and mature plants were cultured on WPM supplemented with $2.2 \mu \mathrm{M}$ TDZ, $2.2 \mu \mathrm{M}$ BA, and $2.5 \mu \mathrm{M}$ IBA. Roots were induced using half-strength MS medium or WPM containing 2.5 or $5 \mu \mathrm{M}$ IBA. Ning and Bao [110] reported a shoot regeneration protocol using immature cotyledons of Prunus mume 'Lv'e' and 'Xuemei'. The best shoot regeneration was obtained on half-strength MS medium containing $2.2 \mu \mathrm{M}$ BA, $2.2 \mu \mathrm{M}$ TDZ, and $1 \mu \mathrm{M}$ IBA. The shoots rooted successfully on WPM supplemented with $5 \mu \mathrm{M}$ IBA.

\section{Prunus persica L. Batsch}

Kalinina and Brown [60] developed a micropropagation approach for ten Prunus species including peach. The shoot proliferation medium consisted of QL basal salt medium supplemented with $1.5 \%$ fructose, $2.2 \mu \mathrm{M}$ BA, $2.5 \mu \mathrm{M}$ IBA, 5.8 $\mu \mathrm{M}$ GA, and 5.1 $\mu \mathrm{M}$ ferulic acid (trans-4hydroxy3-methoxycinnamic acid, FA). Roots developed after a 4-day root induction on half-strength MS medium containing $14.2 \mu \mathrm{M}$ IBA, 5.1 $\mu \mathrm{M}$ FA, and $3 \%$ sucrose followed by 3 -week root elongation in the same medium without IBA. Radmann et al. [141] reported that QL-MS medium enriched with $8.88 \mu \mathrm{M}$ BA produced good shoot proliferation in peach rootstock 'Tsukuba 1'. But for shoot elongation, a reduced concentration of $2.22 \mu \mathrm{M}$ BA was found to be better.

Mante et al. [89] reported shoot regeneration from mature cotyledons of European plum and immature cotyledons of peach. Peach shoots developed on MS medium supplemented with $2.5 \mu \mathrm{M}$ IBA and 5-10 $\mu \mathrm{M}$ TDZ, while European plum regenerated on MS medium supplemented with $2.5 \mu \mathrm{M}$ IBA and 5-12.5 $\mu \mathrm{M}$ TDZ. Roots were induced from peach shoots on half-strength MS medium with $2.5-5 \mu \mathrm{M}$ IBA at a rate of $50-70 \%$, while roots of plum shoots were more difficult to form (20-25\%) and required 3 weeks on plant growth regulator-free medium prior to transfer to the rooting medium described previously. Pooler and Scorza [137] established adventitious shoot regeneration from cotyledons of mature stored seeds of three peach rootstock cultivars when cultured for 3 weeks in darkness on MS medium with $2.5 \%$ sucrose and a combination of IBA ( 1.25 or $2.5 \mu \mathrm{M})$ and TDZ $(6.25$ or $12.5 \mu \mathrm{M})$. Seventy-percent of shoots rooted after being dipped in $2.5 \mathrm{mM}$ IBA and transferred to half-strength MS medium supplemented with $5 \mu \mathrm{M}$ IBA. Declerck and Korban [26] reported the positive effects of glucose and TDZ at $8-13 \mu \mathrm{M}$ on callus induction of wounded leaf explants. Gentile et al. [42] developed an adventitious shoot regeneration protocol from leaf explants of a juvenile and four mature genotypes which involved a 21-day dark treatment in medium containing BA and NAA for callus induction, and another 21-day light treatment for shoot regeneration in auxin-free medium for shoot regeneration. Pérez-Jiménez et al. [121] regenerated shoots from the base of stems by inducing organogenic calli on MS medium containing different levels of BA and IBA followed by transfer to $\mathrm{MS}$ medium with $8.88 \mu \mathrm{M}$ BA and $5.4 \mu \mathrm{M}$ NAA for regeneration. Pérez-Jiménez et al. [122] reported an efficient protocol of callus induction from adult tissues of peach using WPM supplemented with $5.4 \mu \mathrm{M} 2,4-\mathrm{D}$ and $4.6 \mu \mathrm{M}$ kinetin.

\section{Agrobacterium-Mediated Transformation of Prunus Species}

Prunus serotina Ehrh.

An Agrobacterium-mediated transformation protocol for black cherry was reported by Liu and Pijut [79] using leaf explants of an elite mature genotype. Briefly, this protocol involved induction of Agrobacterium virulence using acetosyringone (AS), co-cultivation of wounded leaf explants with Agrobacterium, and selection of putative transgenics on elongation medium after regeneration, 
similar to the protocol developed by Dolgov and Firsov [27] for sour cherry (P. cerasus) using leaf disks. However, the transformation efficiency was only $1.2 \%$. Furthermore, the rooting percentage of transgenic black cherry shoots was low $(37.5 \%)$, and acclimatization and survival were extremely difficult for rooted transgenic black cherry plantlets. Wang and Pijut [179] improved this genetic transformation protocol and rooting of transgenic black cherry shoots. Fifteen-minute vacuum infiltration without sonication produced the highest transformation efficiency $(21.7 \%)$ depending on the binary vector used. Rooting $(30 \%)$ of transgenic black cherry shoots was achieved using half-strength MS medium supplemented with $2 \%$ sucrose, $5 \mu \mathrm{M}$ NAA, $0.01 \mu \mathrm{M}$ kinetin, and $0.793 \mathrm{mM}$ PG. The resulting transgenic plants were successfully acclimatized.

\section{Prunus armeniaca $\mathrm{L}$.}

da Câmara Machado et al. [23] developed a protocol for Agrobacterium-mediated transformation of apricot from cotyledons, and high regeneration rates of transgenic shoots were obtained. The regeneration medium was MS medium supplemented with $2.5 \mu \mathrm{M}$ IBA, $7.5 \mu \mathrm{M}$ TDZ, $0.56 \mathrm{mM}$ myoinositol, $2 \%$ sucrose, and $0.8 \%$ purified agar. This was also the first report of integration of a viral coat protein gene into a fruit tree species. Petri et al. [129] reported the first transformation procedure of apricot leaves with an adult origin. They tested various factors in the process of transformation to increase the efficiency, including the virulence of different Agrobacterium strains, the growth phase of the inocula, infection and co-culture duration, concentration of AS, and the effect of vacuum infiltration. Their study provided a detailed foundation of efficient transformation in apricot as well as in other Prunus spp. Petri et al. [131] reported a more complete protocol of stable transformation of apricot using whole leaf explants, and the transformation efficiency was $5.6 \%$. The regeneration medium and shoot multiplication medium contained QL macronutrients and DKW micronutrients, vitamins, and organic compounds, $3 \%$ sucrose, and $0.7 \%$ agar, but the regeneration medium consisted of $9 \mu \mathrm{M} \mathrm{TDZ}$, $4 \mu \mathrm{M}$ NAA, and $60 \mu \mathrm{M}$ STS, and the shoot multiplication medium was supplemented with $3.1 \mu \mathrm{M}$ BA and $0.2 \mu \mathrm{M}$ IBA. A delay of selection and gradually increased concentration of antibiotics were suggested in order to obtain regenerated shoots [130]. López-Noguera et al. [84] published the first report of using the multi-auto-transformation (MAT) vector system in a temperate fruit tree, apricot, to obtain marker-free transgenic plants with high efficiency. The vector combined the isopentenyl transferase (ipt) gene to promote shoot regeneration and the recombinase system $R /$ RS to remove marker genes from transgenic cells after transformation. The regeneration percentage was $63.3 \%$ when infected shoots were cultured on medium containing QL macronutrients and DKW micronutrients, vitamins and organic compounds, $4.5 \mu \mathrm{M}$ TDZ, $3 \%$ sucrose, and $0.7 \%$ agar. But in this system, the excision required 1 year for the cassette to be completely removed from all transgenic lines, and anomalous recombination was found in $59 \%$ of the marker-free shoots. Therefore, they continued focusing on developing the marker-free transformation system in apricot and published their work on using the chemical-inducible Cre-LoxP system [134]. Addition of $3 \mu \mathrm{M} \beta$-estradiol in the medium induced elimination of marker and recombinase genes. Although this method still had the problem of incomplete DNA excision in some transgenic lines, it provided a possibility of using this system to obtain marker-free transgenic trees. Based on their regeneration protocol from mature apricot cotyledons, Wang et al. [182] developed an efficient Agrobacterium-mediated transformation system using the same type of explants and the use of $10 \mu \mathrm{M}$ paromomycin as the selective agent increased transformation efficiency compared to $10 \mu \mathrm{M}$ kanamycin.

\section{Prunus avium $\mathrm{L}$.}

Piagnani [135] tried to introduce the p35SGUSIntron binary vector carrying rolABC genes from Agrobacterium rhizogenes, GUS, and neomycin phosphotransferase gene (nptII) into the recalcitrant sweet cherry cultivar 'Blurlat C1'. They first examined shoot regeneration from shoot apical portions and rooting. The percentages for both were above $50 \%$. However, no transgenic shoots were able to regenerate after transformation.

\section{Prunus domestica $\mathrm{L}$}

Mante et al. [90] established the first complete protocol for Agrobacterium-mediated transformation and regeneration of plum hypocotyl segments. They developed transgenic plum plants that expressed the plum pox virus coat protein (PPV-CP) gene for disease resistance through Agrobacterium-mediated transformation of hypocotyl slices [156]. Although the transformation rate was relatively low, five transgenic lines with accumulated PPV-CP-immunoreactive protein were obtained. Padilla et al. [117] described an improved plum transformation system by early antibiotic selection at a high level right after co-cultivation to eliminate "escapes," and the use of half-strength MS medium with $5 \mu \mathrm{M}$ NAA and $0.01 \mu \mathrm{M}$ kinetin to achieve $90 \%$ rooting. Mikhailov et al. [99] improved regeneration of plum using leaf explants by adjusting the concentrations and combinations of plant growth regulators, applying explant pretreatment, and using the explants at the optimal 
physiological age, which resulted in $80 \%$ regeneration. However, the transformation efficiency obtained from the same regeneration procedure was very low [98]. Nagel et al. [106] obtained three transgenic plum lines that expressed the Gastrodia antifungal protein, and two of these showed enhanced resistance to Phytophthora root rot (PRR) caused by Phytophthora cinnamomi and the rootknot nematode, Meloidogyne incognita. Wang et al. [181] developed transgenic plum plants that were resistant to PPV through the hairpin-mediated RNA silencing approach. The fragment of viral RNA coding for P1 was constructed as inverted repeats spanned by an intron and was introduced into the plum genome. Fifty-percent of the transgenic lines showed resistance to PPV, which was attributed to post-transcriptional gene silencing. Tian et al. [174] demonstrated that hygromycin as the selectable antibiotic was very effective for plum transformation with embryonic axes. It was found that $5 \mathrm{mg} \mathrm{L}^{-1}$ hygromycin was sufficient to select transgenic shoots, and no escape was observed. This information was useful because, for gene stacking by sequential retransformation, multiple selectable markers are required. Petri et al. [132] developed an efficient transformation system for plum using hypocotyl slices of mature seeds with an average efficiency of $25 \%$. The protocol consisted of 3 days of co-cultivation, shoot regeneration on MS medium with $7.5 \mu \mathrm{M}$ TDZ and $0.25 \mu \mathrm{M}$ IBA, shoot elongation on MS medium with $3 \mu \mathrm{M}$ $\mathrm{BA}$, and rooting on MS medium with $0.1 \mu \mathrm{M}$ kinetin and $5 \mu \mathrm{M}$ NAA. This system was used to produce marker-free plum transformed with an intron-hairpin-RNA (ihpRNA) construct carrying the PPV-CP gene. After regeneration without selection, five transgenic lines were obtained and were confirmed by DNA blot analysis [133]. Wang et al. [184] introduced a new selection marker gene, the Escherichia coli pmi gene encoding the phosphomannose isomerase enzyme, into plum not only because it was effective in selection of transgenic plants, but also because the PMI protein was considered safer to mammals and the environment than marker genes for antibiotic resistance. By conducting GUS assay to monitor the transformation process, the appropriate concentrations of mannose were determined for selection, and several transgenic plants were obtained from hypocotyl explants.

Prunus mume Sieb. et Zucc.

Gao et al. [39] reported the first successful method of somatic embryogenesis and genetic transformation using immature cotyledons of Japanese apricot. The immature cotyledons less than $5 \mathrm{~mm}$ were the best material to use. The somatic embryo induction medium consisted of MS medium with $1 \mu \mathrm{M}$ 2,4-D and $1 \mu \mathrm{M} \mathrm{BA}$, and the somatic embryo propagation medium contained $0.1 \mu \mathrm{M}$ NAA and
$5 \mu \mathrm{M}$ BA. But, the transformation efficiency was low, and there was abnormal development of somatic embryos. GaoTakai and Tao [40] improved the transformation efficiency of Japanese apricot by sonication treatment of immature cotyledons, and the efficiency was evaluated by transient GFP expression and frequency of somatic embryogenesis.

\section{Prunus persica L. Batsch}

Scorza et al. [155] conducted Agrobacterium-mediated transformation of peach using different explants including leaf segments, immature embryos, and long-term embryogenic callus based on the callus induction protocols for different types of explants. However, they did not obtain any transgenic plants, but transgenic embryogenic calli. This study was still important in establishing the standard transformation system and confirming transformants at a molecular level. Pérez-Clemente et al. [120] established the first Agrobacterium-mediated transformation and regeneration system using embryo sections of mature seeds of peach. It involved sonication for $30 \mathrm{~s}$, co-cultivation for 3 days in the dark, and regeneration on QL medium with $7.5 \mu \mathrm{M}$ TDZ and $2.9 \mu \mathrm{M}$ IAA, shoot elongation on QL medium with $4.44 \mu \mathrm{M} \mathrm{BA}$, and rooting on half-strength MS medium with $2.3 \mu \mathrm{M}$ IAA and $5.9 \mu \mathrm{M}$ IBA. Padilla et al. [118] investigated the combination of Agrobacterium strains, plasmids, and promoters on the transformation efficiency of peach using the reporter gene encoding GFP or GUS. They found that a combination of A. tumefaciens EHA105, plasmid pBIN19, and the CaMV35S promoter produced the highest rate of transformation based on GUS expression. But, the GFP expression showed lower transformation efficiency in peach when plasmid pLC101 and the doubleCaMV35S (dCaMV35S) promoter were used, indicating the impact of Agrobacterium strains and plasmids on transformation efficiency.

\section{Summary}

Improved protocols for in vitro micropropagation, regeneration, rooting, and Agrobacterium-mediated genetic transformation of black cherry have been developed. Black cherry floral-related genes ( $A G$ and $T F L l$ ) have been cloned and characterized. The molecular mechanisms that play a role in flowering and the understanding of plantinsect interactions have provided various strategies to modify reproduction and host resistance in black cherry. There are different approaches that are being developed to achieve this goal based on our current knowledge. Effective and durable protection against pests requires the involvement of multimechanistic methods and integrated pest-management strategies to achieve the best results. The 
foundation for genetic improvement of black cherry has been established. Therefore, genetic engineering of black cherry for reproductive sterility and pest resistance is feasible in the near future.

Acknowledgments This work was supported financially by a Fred M. van Eck scholarship for Purdue University to Ying Wang.

Disclaimer Mention of a trademark, proprietary product, or vendor does not constitute a guarantee or warranty of the product by the U.S. Department of Agriculture and does not imply its approval to the exclusion of other products or vendors that also may be suitable.

\section{References}

1. Abe M, Kobayashi Y, Yamamoto S, Daimon Y, Yamaguchi A, Ikeda Y, Ichinoki H, Notaguchi M, Goto K, Araki T (2005) FD, a bZIP protein mediating signals from the floral pathway integrator FT at the shoot apex. Science 309:1052-1056

2. Al-Ahmad H, Galili S, Gressel J (2004) Tandem constructs to mitigate transgene persistence: tobacco as a model. Mol Ecol 13:697-710

3. Al-Ahmad H, Dwyer J, Moloney M, Gressel J (2006) Mitigation of establishment of Brassica napus transgenes in volunteers using a tandem construct containing a selectively unfit gene. Plant Biotechnol J 4:7-21

4. Amelot MEA, Nunez JLA, Duarte L, Oliveros-Bastidas A (2006) Hydrogen cyanide release during feeding of generalist and specialist lepidopteran larvae on a cyanogenic plant, Passiflora capsularis. Physiol Entomol 31:307-315

5. An H, Roussot C, Suárez-López P, Corbesier L, Vincent C, Piñeiro M, Hepworth S, Mouradov A, Justin S, Turnbull C, Coupland G (2004) CONSTANS acts in the phloem to regulate a systemic signal that induces photoperiodic flowering of Arabidopsis. Development 131:3615-3626

6. An XM, Wang DM, Wang ZL, Li B, Bo WH, Cao GL, Zhang ZY (2011) Isolation of a LEAFY homolog from Populus tomentosa: expression of PtLFY in P. tomentosa floral buds and $P t L F Y$-IR-mediated gene silencing in tobacco (Nicotiana tabacum). Plant Cell Rep 30:89-100

7. Argiriou A, Michailidis G, Tsaftaris AS (2008) Characterization and expression analysis of TERMINAL FLOWER1 homologs from cultivated alloteraploid cotton (Gossypium hirsutum) and its diploid progenitors. J Plant Physiol 165:1636-1646

8. Baleriola-Lucas C, Mullins M (1984) Micropropagation of two French prune cultivars. Agronomie 4:473-477

9. Ballhorn DJ, Heil M, Pietrowski A, Lieberei R (2007) Quantitative effects of cyanogenesis on an adapted herbivore. J Chem Ecol 33:2195-2208

10. Ballhorn DJ, Kautz S, Lieberei R (2010) Comparing responses of generalist and specialist herbivores to various cyanogenic plant features. Entomol Exp Appl 134:245-259

11. Barnd B, Ginzel MD (2008) Causes of gummosis in black cherry (Prunus serotina). USDA Forest Service and Purdue University, FNR-229-W

12. Bhagwat B, Lane WD (2004) In vitro shoot regeneration from leaves of sweet cherry (Prunus avium) 'Lapins' and 'Sweetheart'. Plant Cell Tissue Organ 78:173-181

13. Bock R (2007) Plastid biotechnology: prospects for herbicide and insect resistance, metabolic engineering and molecular farming. Curr Opin Biotechnol 18:100-106

14. Bortiri E, Oh SH, Jiang JG, Baggett S, Granger A, Weeks C, Buckingham M, Potter D, Parfitt DE (2001) Phylogeny and systematics of Prunus (Rosaceae) as determined by sequence analysis of ITS and the chloroplast $\operatorname{trnL-trnF}$ spacer DNA. Syst Bot 26:797-807

15. Bortiri E, Heuvel BV, Potter D (2006) Phylogenetic analysis of morphology in Prunus reveals extensive homoplasy. Plant Syst Evol 259:53-71

16. Boss PK, Sreekantan L, Thomas MR (2006) A grapevine TFL1 homologue can delay flowering and alter floral development when overexpressed in heterologous species. Funct Plant Biol 33:31-41

17. Brill EM, Watson JM (2004) Ectopic expression of a Eucalyptus grandis $S V P$ orthologue alters the flowering time of Arabidopsis thaliana. Funct Plant Biol 31:217-224

18. Canli FA, Tian L (2008) In vitro shoot regeneration from stored mature cotyledons of sweet cherry (Prunus avium L.) cultivars. Sci Hortic 116:34-40

19. Carrasco B, Meisel L, Gebauer M, Garcia-Gonzales R, Silva H (2013) Breeding in peach, cherry and plum: from a tissue culture, genetic, transcriptomic and genomic perspective. Biol Res 46:219-230

20. Chen Y, Jiang P, Thammannagowda S, Liang H, Wilde HD (2013) Characterization of peach TFL1 and comparison with FT/ TFL1 gene families of the Rosaceae. J Am Soc Hortic Sci 138:12-17

21. Cheng IP, Poulton JE (1993) Cloning of cDNA of Prunus serotina (R)-(+)-mandelonitrile lyase and identification of a putative FAD-binding site. Plant Cell Physiol 34:1139-1143

22. Clarke JL, Daniell H (2011) Plastid biotechnology for crop production: present status and future perspectives. Plant Mol Biol 76:211-220

23. da Câmara Machado ML, da Câmara Machado A, Hanzer V, Weiss H, Regner F, Steinkellner H, Mattanovich D, Plail R, Knapp E, Kalthoff B, Katinger H (1992) Regeneration of transgenic plants of Prunus armeniaca containing the coat protein gene of plum pox virus. Plant Cell Rep 11:25-29

24. Daniell H (2002) Molecular strategies for gene containment in transgenic crops. Nat Biotechnol 20:581-586

25. Danilevskaya ON, Meng X, Ananiev EV (2010) Concerted modification of flowering time and inflorescence architecture by ectopic expression of TFL1-like genes in maize. Plant Physiol 153:238-251

26. Declerck V, Korban SS (1996) Influence of growth regulators and carbon sources on callus induction, growth and morphogenesis from leaf tissues of peach (Prunus persica L. Batsch). J Hortic Sci 71:49-55

27. Dolgov SV, Firsov AP (1999) Regeneration and Agrobacterium transformation of sour cherry leaf discs. Acta Hortic 484:577-580

28. Downey SL, Iezzoni AF (2000) Polymorphic DNA markers in black cherry (Prunus serotina) are identified using sequences from sweet cherry, peach, and sour cherry. J Am Soc Hortic Sci 125:76-80

29. Drew AP, Kavanagh KL, Maynard CA (1992) Acclimatizing micropropagated black cherry by comparison with half-sib seedlings. Physiol Plantarum 86:459-464

30. Driver JA, Kuniyuki AH (1984) In vitro propagation of Paradox walnut rootstock. HortScience 19:507-509

31. Duan YX, Fan J, Guo WW (2010) Regeneration and characterization of transgenic kumquat plants containing the Arabidopsis APETALA1 gene. Plant Cell Tissue Org 100:273-281

32. Durkovič J (2006) Rapid micropropagation of mature wild cherry. Biol Plant 50:733-736

33. Escalettes V, Dosba F (1993) In vitro adventitious shoot regeneration from leaves of Prunus spp. Plant Sci 90:201-209

34. Espinosa AC, Pijut PM, Michler CH (2006) Adventitious shoot regeneration and rooting of Prunus serotina in vitro cultures. HortScience 41:193-201 
35. Feeney M, Bhagwat B, Mitchell JS, Lane WD (2007) Shoot regeneration from organogenic callus of sweet cherry (Prunus avium L.). Plant Cell Tiss Org 90:201-214

36. Fitzgerald TD (2008) Larvae of the fall webworm, Hyphantria cunea, inhibit cyanogenesis in Prunus serotina. J Exp Biol 211:671-677

37. Fitzgerald TD, Jeffers PM, Mantella D (2002) Depletion of host derived cyanide in the gut of the eastern tent caterpillar, $\mathrm{Ma}$ lacosoma americanum. J Chem Ecol 28:257-268

38. Flachowsky H, Szankowski I, Waidmann S, Peil A, Tränkner C, Hanke MV (2012) The MdTFL1 gene of apple (Malus x domestica Borkh.) reduces vegetative growth and generation time. Tree Physiol 32:1288-1301

39. Gao M, Kawabe M, Tsukamoto T, Hanada H, Tao R (2010) Somatic embryogenesis and Agrobacterium-mediated transformation of Japanese apricot (Prunus mume) using immature cotyledons. Sci Hortic 124:360-367

40. Gao-Takai M, Tao R (2014) Improving infection efficiency of Agrobacterium to immature cotyledon explants of Japanese apricot (Prunus mume) by sonication treatment. J Jpn Soc Hortic Sci 83:108-116

41. Gatchell CJ (1971) Black cherry (Prunus serotina Ehrh.). FS229

42. Gentile A, Monticelli S, Damiano C (2002) Adventitious shoot regeneration in peach [Prunus persica (L.) Batsch]. Plant Cell Rep 20:1011-1016

43. Goetz M, Godt DE, Guivarc'h A, Kahmann U, Chriqui D, Roitsch T (2001) Induction of male sterility in plants by metabolic engineering of the carbohydrate supply. Proc Natl Acad Sci USA 98:6522-6527

44. Goffreda JC, Scopel AL, Fiola JA (1995) Indole butyric acid induces regeneration of phenotypically normal apricot (Prunus armeniaca L) plants from immature embryos. Plant Growth Regul 17:41-46

45. González-Schain ND, Suárez-López P (2008) CONSTANS delays flowering and affects tuber yield in potato. Biol Plant 52:251-258

46. Goto K, Meyerowitz EM (1994) Function and regulation of the Arabidopsis floral homeotic gene PISTILLATA. Genes Dev 8:1548-1560

47. Grant NJ, Hammatt N (2000) Adventitious shoot development from wild cherry (Prunus avium L.) leaves. New For 20:287-295

48. Gressel J (2014) Dealing with transgene flow of crop protection traits from crops to their relatives. Pest Manag Sci. doi:10.1002/ ps.3850

49. Hammatt N, Grant NJ (1997) Micropropagation of mature British wild cherry. Plant Cell Tiss Org 47:103-110

50. Hammatt N, Grant NJ (1998) Shoot regeneration from leaves of Prunus serotina Ehrh. (black cherry) and P. avium L. (wild cherry). Plant Cell Rep 17:526-530

51. Hanano S, Goto K (2011) Arabidopsis TERMINAL FLOWER1 is involved in the regulation of flowering time and inflorescence development through transcriptional repression. Plant Cell 23:3172-3184

52. Harada H, Murai Y (1996) Micropropagation of Prunus mume. Plant Cell Tiss Org 46:265-267

53. Hartmann U, Höhmann S, Nettesheim K, Wisman E, Saedler H, Huijser P (2000) Molecular cloning of SVP: a negative regulator of the floral transition in Arabidopsis. Plant J 21:351-360

54. Hasunuma T, Kondo A, Miyake C (2009) Metabolic pathway engineering by plastid transformation is a powerful tool for production of compounds in higher plants. Plant Biotechnol 26:39-46

55. Hoenicka H, Lehnhardt D, Polak O, Fladung M (2012) Early flowering and genetic containment studies in transgenic poplar. iForest-Biogeosc For 5:138
56. Horlow C, Goujaud J, Lépingle A, Missonier C, Bourgin JP (1990) Transmission of paternal chloroplasts in tobacco (Nicotiana tabacum). Plant Cell Rep 9:249-252

57. Hough AF (1965) Black cherry (Prunus serotina Ehrh.). In: Fowells HA (ed) Silvics of forest trees of the United States, Agriculture Handbook, vol 271. USDA Forest Service, Washington, DC, pp 539-545

58. Hu Z, Poulton JE (1999) Molecular analysis of (R)-(+)-mandelonitrile lyase microheterogeneity in black cherry. Plant Physiol 119:1535-1546

59. Jack T, Brockman LL, Meyerowitz EM (1992) The homeotic gene APETALA3 of Arabidopsis thaliana encodes a MADS box and is expressed in petals and stamens. Cell 68:683-697

60. Kalinina A, Brown DC (2007) Micropropagation of ornamental Prunus spp. and GF305 peach, a Prunus viral indicator. Plant Cell Rep 26:927-935

61. Keenan RJ, Stemmer WP (2002) Nontransgenic crops from transgenic plants. Nat Biotechnol 20:215-216

62. Kempin SA, Savidge B, Yanofsky MF (1995) Molecular basis of the cauliflower phenotype in Arabidopsis. Science 267:522-525

63. Kiani S, Mohamed BB, Jamal A, Shahid MN, Shehzad K, Shahid AA, Husnain T (2013) Chloroplast-targeted expression of recombinant crystal-protein gene in cotton: an unconventional combat with resistant pests. J Biotechnol 166:88-96

64. Kobayashi Y, Kaya H, Goto K, Iwabuchi M, Araki T (1999) A pair of related genes with antagonistic roles in mediating flowering signals. Science 286:1960-1962

65. Kotake T, Takada S, Nakahigashi K, Ohto M, Goto K (2003) Arabidopsis TERMINAL FLOWER 2 gene encodes a heterochromatin protein 1 homolog and represses both FLOWERING LOCUS T to regulate flowering time and several floral homeotic genes. Plant Cell Physiol 44:555-564

66. Kotoda N, Wada M (2005) MdTFL1, a TFL1-like gene of apple, retards the transition from the vegetative to reproductive phase in transgenic Arabidopsis. Plant Sci 168:95-104

67. Kotoda N, Iwanami H, Takahashi S, Abe K (2006) Antisense expression of MdTFL1, a TFL1-like gene, reduces the juvenile phase in apple. J Am Soc Hortic Sci 131:74-81

68. Kulman HM (1964) Defects in black cherry caused by bark beetles and agromizid cambium miners. For Sci 10:258-266

69. Kuparinen A, Schurr FM (2008) Assessing the risk of gene flow from genetically modified trees carrying mitigation transgenes. Biol Invasions 10:281-290

70. Lane WD, Cossio F (1986) Adventitious shoots from cotyledons of immature cherry and apricot embryos. Can J Plant Sci 66:953-959

71. Lee D, Natesan E (2006) Evaluating genetic containment strategies for transgenic plants. Trends Biotechnol 24:109-114

72. Lee H, Suh SS, Park E, Cho E, Ahn JH, Kim SG, Lee JS, Kwon YM, Lee I (2000) The AGAMOUS-LIKE 20 MADS domain protein integrates floral inductive pathways in Arabidopsis. Genes Dev 14:2366-2376

73. Lee JH, Yoo SJ, Park SH, Hwang I, Lee JS, Ahn JH (2007) Role of $S V P$ in the control of flowering time by ambient temperature in Arabidopsis. Genes Dev 21:397-402

74. Li ZM, Zhang JZ, Mei L, Deng XX, Hu CG, Yao JL (2010) PtSVP, an SVP homolog from trifoliate orange (Poncirus trifoliata L. Raf.), shows seasonal periodicity of meristem determination and affects flower development in transgenic Arabidopsis and tobacco plants. Plant Mol Biol 74:129-142

75. Liang HY, Zhebentyayeva T, Olukolu B, Wilde D, Reighard GL, Abbott A (2010) Comparison of gene order in the chromosome region containing a TERMINAL FLOWER 1 homolog in apricot and peach reveals microsynteny across angiosperms. Plant Sci 179:390-398 
76. Lin C, Fang J, Xu X, Zhao T, Cheng J, Tu J, Ye G, Shen Z (2008) A built-in strategy for containment of transgenic plants: creation of selectively terminable transgenic rice. PLoS ONE 3(3): 1818

77. Liu Z, Liu Z (2008) The second intron of AGAMOUS drives carpel-and stamen-specific expression sufficient to induce complete sterility in Arabidopsis. Plant Cell Rep 27:855-863

78. Liu X, Pijut PM (2008) Plant regeneration from in vitro leaves of mature black cherry (Prunus serotina). Plant Cell Tissue Organ 94:113-123

79. Liu X, Pijut PM (2010) Agrobacterium-mediated transformation of mature Prunus serotina (black cherry) and regeneration of transgenic shoots. Plant Cell Tissue Organ 101:49-57

80. Liu Z, Zhou C, Wu K (2008) Creation and analysis of a novel chimeric promoter for the complete containment of pollen-and seed-mediated gene flow. Plant Cell Rep 27:995-1004

81. Liu B, Watanabe S, Uchiyama T, Kong F, Kanazawa A, Xia Z, Nagamatsu A, Arai M, Yamada T, Kitamura K, Masuta C, Harada K, Abe J (2010) The soybean stem growth habit gene Dt1 is an ortholog of Arabidopsis TERMINAL FLOWER1. Plant Physiol 153:198-210

82. Liu X, Anderson JM, Pijut PM (2010) Cloning and characterization of Prunus serotina AGAMOUS, a putative flower homeotic gene. Plant Mol Biol Rep 28:193-203

83. Lloyd G, McCown LB (1981) Commercially-feasible micropropagation of mountain laurel, Kalmia latifolia, by use of shoot-tip culture. Comb Proc Int Plant Prop Soc 30:421-427

84. López-Noguera S, Petri C, Burgos L (2009) Combining a regeneration-promoting ipt gene and site-specific recombination allows a more efficient apricot transformation and the elimination of marker genes. Plant Cell Rep 28:1781-1790

85. Luo K, Duan H, Zhao D, Zheng X, Deng W, Chen Y, Stewart CN Jr, McAvoy R, Jiang X, Wu Y, He A, Pei Y, Li Y (2007) 'GM-gene-deletor': fused loxP-FRT recognition sequences dramatically improve the efficiency of FLP or CRE recombinase on transgene excision from pollen and seed of tobacco plants. Plant Biotechnol J 5:263-374

86. Madhuri B, Raut S, Dey D, Nazneen A, Uma B, Podile AR (2012) Tapetum-specific expression of harpinPss causes male sterility in transgenic tobacco. Biol Plant 56:628-634

87. Maldaner FR, Aragão FJL, dos Santos FB, Franco OL, Lima MDRQ, de Oliveira RR, Vasques RM, Nagata T (2013) Dengue virus tetra-epitope peptide expressed in lettuce chloroplasts for potential use in dengue diagnosis. Appl Microbiol Biotechnol 97:5721-5729

88. Mandel MA, Gustafson-Brown C, Savidge B, Yanofsky MF (1992) Molecular characterization of the Arabidopsis floral homeotic gene APETALA1. Nature 360:273-277

89. Mante S, Scorza R, Cordts JM (1989) Plant regeneration from cotyledons of Prunus persica, Prunus domestica, and Prunus cerasus. Plan Cell Tissue Organ 19:1-11

90. Mante S, Morgens PH, Scorza R, Cordts JM, Callahan AM (1991) Agrobacterium-mediated transformation of plum (Prunus domestica L.) hypocotyl slices and regeneration of transgenic plants. Nat Biotechnol 9:853-857

91. Mariani C, Beuckeleer MD, Truettner J, Leemans J, Goldberg RB (1990) Induction of male sterility in plants by a chimaeric ribonuclease gene. Nature 347:737-741

92. Marquis DA (1975) Seed storage and germination under northern hardwood forests. Can J For Res 5:478-484

93. Marquis DA (1990) Prunus serotina Ehrh. Black Cherry. In: Burns RM, Honkala BH (eds) Silvics of North America, vol 2, Hardwoods, USDA Forest Service, Washington, DC, pp 594-604

94. Matt A, Jehle JA (2005) In vitro plant regeneration from leaves and internode sections of sweet cherry cultivars (Prunus avium L.). Plant Cell Rep 24:468-476
95. Mayer KF, Schoof H, Haecker A, Lenhard M, Jürgens G, Laux $\mathrm{T}$ (1998) Role of WUSCHEL in regulating stem cell fate in the Arabidopsis shoot meristem. Cell 95:805-815

96. Maynard CA, Kavanagh K, Fuernkranz H, Drew AP (1991) Black cherry (Prunus serotina Ehrh.). In: Bajaj YPS (ed) Trees III. Springer, Berlin, pp 3-22

97. Michaels SD, Amasino RM (1999) FLOWERING LOCUS C encodes a novel MADS domain protein that acts as a repressor of flowering. Plant Cell 11:949-956

98. Mikhailov R, Dolgov S (2007) Transgenic plum (Prunus domestica L.) plants obtained by Agrobacterium-mediated transformation of leaf explants with use of various selective agents. Acta Hortic 738:613-623

99. Mikhailov RV, Muratova SA, Dolgov SV (2004) Production of transgenic plum plants from vegetative tissues by means of positive selection. Acta Hortic 734:129-138

100. Mitsuda N, Hiratsu K, Todaka D, Nakashima K, YamaguchiShinozaki K, Ohme-Takagi M (2006) Efficient production of male and female sterile plants by expression of a chimeric repressor in Arabidopsis and rice. Plant Biotechnol J 4:325-332

101. Møller BL (2010) Functional diversifications of cyanogenic glucosides. Curr Opin Plant Biol 13:338-347

102. Moon HS, Li Y, Stewart CN Jr (2010) Keeping the genie in the bottle: transgene biocontainment by excision in pollen. Trends Biotechnol 28:3-8

103. Moon HS, Abercrombie LL, Eda S, Blanvillain R, Thomson JG, Ow DW, Stewart CN Jr (2011) Transgene excision in pollen using a codon optimized serine resolvase CinH-RS2 site-specific recombination system. Plant Mol Biol 75:621-631

104. Muna AS, Ahmad AK, Mahmoud K, Abdul-Rahman K (1999) In vitro propagation of a semi-dwarfing cherry rootstock. Plant Cell Tiss Org 59:203-208

105. Murashige T, Skoog F (1962) A revised medium for rapid growth and bio assays with tobacco tissue cultures. Physiol Plantarum 15:473-497

106. Nagel AK, Schnabel G, Petri C, Scorza R (2008) Generation and characterization of transgenic plum lines expressing the Gastrodia antifungal protein. HortScience 43:1514-1521

107. Nair SK, Wang N, Turuspekov Y, Pourkheirandish M, Sinsuwongwat S, Chen G, Sameri M, Tagiri A, Honda I, Watanabe Y, Kanamori H, Wicker T, Stein N, Nagamura Y, Matsumoto T, Komatsuda T (2010) Cleistogamous flowering in barley arises from the suppression of microRNA-guided $H v A P 2$ mRNA cleavage. Proc Natl Acad Sci USA 107:490-495

108. Nakagawa M, Shimamoto K, Kyozuka J (2002) Overexpression of RCN1 and RCN2, rice TERMINAL FLOWER 1/CENTRORADIALIS homologs, confers delay of phase transition and altered panicle morphology in rice. Plant J 29:743-750

109. Narayanan NN, Ihemere U, Ellery C, Sayre RT (2011) Overexpression of hydroxynitrile lyase in cassava roots elevates protein and free amino acids while reducing residual cyanogen levels. PLoS ONE 6(7):e21996

110. Ning GG, Bao MZ (2007) Plant regeneration from callus derived from immature embryo cotyledons of Prunus mите. HortScience 42:744-747

111. Ning GG, Fan XL, Huang WJ, Bao MZ, Zhang JB (2007) Micropropagation of six Prunus mume cultivars through axillary shoot proliferation, and issr analysis of cloned plants. Acta Biologica Cracoviensia Series Botanica 49:25-31

112. Nowak B, Miczyński K, Hudy L (2004) Sugar uptake and utilization during adventitious bud differentiation on in vitro leaf explants of 'Wegierka Zwykła'plum (Prunus domestica). Plant Cell Tissue Organ 76:255-260

113. Nowak B, Miczyński K, Hudy L (2007) The effect of total inorganic nitrogen and the balance between its ionic forms on adventitious bud formation and callus growth of 'Węgierka 
Zwykła'plum (Prunus domestica L.). Acta Physiol Plantarum 29:479-484

114. Ohshima S, Murata M, Sakamoto W, Ogura Y, Motoyoshi F (1997) Cloning and molecular analysis of the Arabidopsis gene Terminal Flower 1. Mol Gen Genet 254:186-194

115. Packer A, Clay K (2000) Soil pathogens and spatial patterns of seedling mortality in a temperate tree. Nature 404:278-281

116. Packer A, Clay K (2004) Development of negative feedback during successive growth cycles of black cherry. Proc R Soc Lond B 271:317-324

117. Padilla IG, Webb K, Scorza R (2003) Early antibiotic selection and efficient rooting and acclimatization improve the production of transgenic plum plants (Prunus domestica L.). Plant Cell Rep 22:38-45

118. Padilla IM, Golis A, Gentile A, Damiano C, Scorza R (2006) Evaluation of transformation in peach Prunus persica explants using green fluorescent protein (GFP) and beta-glucuronidase (GUS) reporter genes. Plant Cell Tissue Org 84:309-314

119. Pelaz S, Gustafson-Brown C, Kohalmi SE, Crosby WL, Yanofsky MF (2001) APETALA1 and SEPALLATA3 interact to promote flower development. Plant J 26:385-394

120. Pérez-Clemente RM, Pérez-Sanjuán A, García-Férriz L, Beltrán JP, Cañas LA (2005) Transgenic peach plants (Prunus persica L.) produced by genetic transformation of embryo sections using the green fluorescent protein (GFP) as an in vivo marker. Mol Breeding 14:419-427

121. Pérez-Jiménez M, Carrillo-Navarro A, Cos-Terrer J (2012) Regeneration of peach (Prunus persica L. Batsch) cultivars and Prunus persica $\mathrm{x}$ Prunus dulcis rootstocks via organogenesis. Plant Cell Tissue Organ 108:55-62

122. Pérez-Jiménez M, López-Soto MB, Cos-Terrer J (2013) In vitro callus induction from adult tissues of peach (Prunus persica $\mathrm{L}$. Batsch). In Vitro Cell Dev Biol Plant 49:79-84

123. Pérez-Tornero O, Burgos L (2000) Different media requirements for micropropagation of apricot cultivars. Plant Cell Tissue Organ 63:133-141

124. Pérez-Tornero O, Burgos L, Egea J (1999) Introduction and establishment of apricot in vitro through regeneration of shoots from meristem tips. In Vitro Cell Dev Biol Plant 35:249-253

125. Pérez-Tornero O, Egea J, Vanoostende A, Burgos L (2000) Assessment of factors affecting adventitious shoot regeneration from in vitro cultured leaves of apricot. Plant Sci 158:61-70

126. Petitpierre B, Pairon M, Broennimann O, Jacquemart AL, Guisan A, Besnard G (2009) Plastid DNA variation in Prunus serotina var. serotina (Rosaceae), a North American tree invading Europe. Eur J For Res 128:431-436

127. Petolino JF, Worden A, Curlee K, Connell J, Strange Moynahan TL, Larsen C, Russel S (2010) Zinc finger nuclease-mediated transgene deletion. Plant Mol Biol 73:617-628

128. Petri C, Scorza R (2010) Factors affecting adventitious regeneration from in vitro leaf explants of 'Improved French' plum, the most important dried plum cultivar in the USA. Ann Appl Biol 156:79-89

129. Petri C, Alburquerque N, García-Castillo S, Egea J, Burgos L (2004) Factors affecting gene transfer efficiency to apricot leaves during early Agrobacterium-mediated transformation steps. J Hortic Sci Biotech 79:704-712

130. Petri C, López-Noguera S, Alburquerque N, Egea J, Burgos L (2008) An antibiotic based selection strategy to regenerate transformed plants from apricot leaves with high efficiency. Plant Sci 175:777-783

131. Petri C, Wang H, Alburquerque N, Faize M, Burgos L (2008) Agrobacterium-mediated transformation of apricot (Prunus armeniaca L.) leaf explants. Plant Cell Rep 27:1317-1324

132. Petri C, Webb K, Hily JM, Dardick C, Scorza R (2008) High transformation efficiency in plum (Prunus domestica L.): a new tool for functional genomics studies in Prunus spp. Mol Breeding 22:581-591

133. Petri C, Hily JM, Vann C, Dardick C, Scorza R (2011) A highthroughput transformation system allows the regeneration of marker-free plum plants (Prunus domestica). Ann Appl Biol 159:302-315

134. Petri C, López-Noguera S, Wang H, García-Almodóvar C, Alburquerque N, Burgos L (2012) A chemical-inducible Cre-LoxP system allows for elimination of selection marker genes in transgenic apricot. Plant Cell Tissue Organ 110:337-346

135. Piagnani MC (2010) Shoot regeneration, in vitro performances of regenerated shoots and transient expression in morphogenic explants in Prunus avium cultivar 'Burlat C1'. Euro J Hortic Sci 75:132-138

136. Pieterse RE (1989) Regeneration of plants from callus and embryos of 'Royal'apricot. Plant Cell Tissue Organ 19:175-179

137. Pooler MR, Scorza R (1995) Regeneration of peach [Prunus persica (L.) Batsch] rootstock cultivars from cotyledons of mature stored seed. HortScience 30:355-356

138. Potter D (2011) Prunus. In: Kole C (ed) Wild crop relatives: genomic and breeding resources. Springer, Berlin, pp 129-145

139. Putterill J, Robson F, Lee K, Simon R, Coupland G (1995) The CONSTANS gene of Arabidopsis promotes flowering and encodes a protein showing similarities to zinc finger transcription factors. Cell 80:847-857

140. Quoirin M, Lepoivre P (1977) Étude des milieux adaptés aux cultures in vitro de Prunus. Acta Hortic 78:437-442

141. Radmann EB, Bianchi VJ, Oliveira RPD, Fachinelo JC (2009) In vitro multiplication and elongation of the micropropagation shoots of the rootstock of 'Tsukuba 1' (Prunus persica L.). Revista Brasileira de Fruticultura 31:656-663

142. Rai MK, Shekhawat NS (2014) recent advances in genetic engineering for improvement of fruit crops. Plant Cell Tissue Organ 116:1-15

143. Ratcliffe OJ, Bradley DJ, Coen ES (1999) Separation of shoot and floral identity in Arabidopsis. Development 126:1109-1120

144. Reilly CC, Gentry CR, Mcvay JR (1987) Biochemical-evidence for resistance of rootstocks to the peachtree borer and species separation of peachtree borer and lesser peachtree borer (Lepidoptera, Sesiidae) on peach-trees. J Econ Entomol 80:338-343

145. Reinhart KO, Tytgat T, Van der Putten WH, Clay K (2010) Virulence of soil-borne pathogens and invasion by Prunus serotina. New Phytol 186:484-495

146. Rosenberger DA (1982) Biology and control of Cytospora fungi in peach plantings. NY Food Life Sci Bull 92:1-6

147. Ruf S, Karcher D, Bock R (2007) Determining the transgene containment level provided by chloroplast transformation. Proc Natl Acad Sci USA 104:6998-7002

148. Ruiz ON, Daniell H (2005) Engineering cytoplasmic male sterility via the chloroplast genome by expression of $\beta$-ketothiolase. Plant Physiol 138:1232-1246

149. Ružić DV, Vujović TI (2008) The effects of cytokinin types and their concentration on in vitro multiplication of sweet cherry $\mathrm{cv}$. Lapins (Prunus avium L.). Hortic Sci 35:12-21

150. Sánchez-Pérez R, del Cueto J, Dicenta F, Martínez-Gómez (2014) Recent advancements to study flowering time in almond and other Prunus species. Front Plant Sci 5:334. doi:10.3389/ fpls.2014.00334

151. Saniewski M, Ueda J, Miyamoto K, Horbowicz M, Puchalski J (2006) Hormonal control of gummosis in Rosaceae. J Fruit Ornam Plant Res 14:137-144

152. Sato H, Yoshida K, Mitsuda N, Ohme-Takagi M, Takamizo T (2012) Male-sterile and cleistogamous phenotypes in tall fescue induced by chimeric repressors of SUPERWOMAN1 and OsMADS58. Plant Sci 183:183-189

153. Scaltsoyiannes A, Tsoulpha P, Iliev I, Theriou K, Tsaktsira M, Mitras D, Karanikas C, Mahmout S, Christopoulos V, 
Scaltsoyiannes V, Zaragotas D, Tzouvara A (2009) Vegetative propagation of ornamental genotypes of Prunus avium L. Prop Ornam Plant 9:198-206

154. Schernthaner JP, Fabijanski SF, Arnison PG, Racicot M, Robert LS (2003) Control of seed germination in transgenic plants based on the segregation of a two component genetic system. Proc Natl Acad Sci USA 100:6855-6859

155. Scorza R, Morgens PH, Cordts JM, Mante S, Callahan AM (1990) Agrobacterium-mediated transformation of peach (Prunus persica $\mathrm{L}$. Batsch) leaf segments, immature embryos, and long-term embryogenic callus. In Vitro Cell Dev Biol 26:829-834

156. Scorza R, Ravelonandro M, Callahan AM, Cordts JM, Fuchs M, Dunez J, Gonsalves D (1994) Transgenic plums (Prunus domestica L.) express the plum pox virus coat protein gene. Plant Cell Rep 14:18-22

157. Searle I, He Y, Turck F, Vincent C, Fornara F, Kröber S, Amasino RA, Coupland G (2006) The transcription factor FLC confers a flowering response to vernalization by repressing meristem competence and systemic signaling in Arabidopsis. Genes Dev 20:898-912

158. Sedlak J, Paprstein F (2008) In vitro shoot proliferation of sweet cherry cultivars Karesova and Rivan. Hortic Sci 35:95-98

159. Selmar D, Lieberei R, Biehl B, Conn EE (1989) $\alpha$-Hydroxynitrile lyase in Hevea brasiliensis and its significance for rapid cyanogenesis. Physiol Plant 75:97-101

160. Shatnawi MA, Shibli R, Qrunfleh I, Bataeineh K, Obeidat M (2007) In vitro propagation and cryopreservation of Prunus avium using vitrification and encapsulation dehydration methods. J Food Agric Environ 5:204-208

161. Shaw J, Small RL (2004) Addressing the "hardest puzzle in American pomology": phylogeny of Prunus sect. Prunocerasus (Rosaceae) based on seven noncoding chloroplast DNA regions. Am J Bot 91:985-996

162. Sinha R, Rajam MV (2013) RNAi silencing of three homologues of Sadenosylmethionine decarboxylase gene in tapetal tissue of tomato results in male sterility. Plant Mol Biol 82:169-180

163. Siritunga D, Arias-Garzon D, White W, Sayre RT (2004) Overexpression of hydroxynitrile lyase in transgenic cassava roots accelerates cyanogenesis and food detoxification. Plant Biotechnol J 2:37-43

164. Suárez-López P, Wheatley K, Robson F, Onouchi H, Valverde F, Coupland G (2001) CONSTANS mediates between the circadian clock and the control of flowering in Arabidopsis. Nature 410:1116-1120

165. Swain E, Poulton JE (1994) Utilization of amygdalin during seedling development of Prunus serotina. Plant Physiol 106:437-445

166. Swain E, Li CP, Poulton JE (1992) Development of the potential for cyanogenesis in maturing black cherry (Prunus serotina Ehrh.) fruits. Plant Physiol 98:1423-1428

167. Szankowski I, Waidmann S, El-Din Saad Omar A, Flachowsky H, Hättasch C, Hanke MV (2009) RNAi-silencing of MdTFL1 induces early flowering in apple. Acta Hortic 839:633-636

168. Tadege M, Sheldon CC, Helliwell CA, Upadhyaya NM, Dennis ES, Peacock WJ (2003) Reciprocal control of flowering time by OsSOC1 in transgenic Arabidopsis and by FLC in transgenic rice. Plant Biotechnol J 1:361-369

169. Tang H, Ren Z, Reustle G, Krczal G (2002) Plant regeneration from leaves of sweet and sour cherry cultivars. Sci Hortic 93:235-244

170. Tattersall DB, Bak S, Jones PR, Olsen CE, Nielsen JK, Hansen ML, Hoj PB, Moller BL (2001) Resistance to an herbivore through engineered cyanogenic glucoside synthesis. Science 293:1826-1828
171. Theißen G (2001) Development of floral organ identity: stories from the MADS house. Curr Opin Plant Biol 4:75-85

172. Theissen G, Becker A, Di Rosa A, Kanno A, Kim JT, Muüster T, Winter K-U, Saedler H (2000) A short history of MADS-box genes in plants. Plant Mol Biol 42:115-149

173. Tian L, Sibbald S, Subramanian J, Svircev A (2007) Characterization of Prunus domestica L. in vitro regeneration via hypocotyls. Sci Hortic 112:462-466

174. Tian L, Canli FA, Wang X, Sibbald S (2009) Genetic transformation of Prunus domestica L. using the hpt gene coding for hygromycin resistance as the selectable marker. Sci Hort 119:339-343

175. Tricoli DM, Maynard CA, Drew AP (1985) Tissue culture of propagation of mature trees of Prunus serotina Ehrh. I. Establishment, multiplication, and rooting in vitro. For Sci 31:201-208

176. Vasar V, Pae A, Jänes H (1998) Influence of nitrogen content and cytokinin source on Prunus domestica L. proliferation and elongation in vitro. Acta Hortic 478:341-346

177. Vicente AR, Manganaris G, Cisneros-Zevallos L, Crisosto $\mathrm{CH}$ (2011) Prunus. In: Terry LA (ed) Health-promoting properties of fruits and vegetables, Chapter 13, CABI, Oxfordshire, UK, pp. $238-260$

178. Wang Y, Pijut PM (2013) Isolation and characterization of a TERMINAL FLOWER 1 homolog from Prunus serotina Ehrh. Tree Physiol 33:855-865

179. Wang Y, Pijut PM (2014) Improvement of Agrobacteriummediated transformation and rooting of black cherry. In Vitro Cell Dev Biol-Plant 50:307-316

180. Wang Y, Pijut PM (2014) Agrobacterium-mediated transformation of black cherry for flowering control and insect resistance. Plant Cell Tissue Organ. doi:10.1007/s11240-014-0517-1

181. Wang A, Tian L, Huang TS, Brown DCW, Svircev AM, Stobbs LW, Miki B, Sanfaçon H (2009) The development of genetic resistance to plum pox virus in transgenic Nicotiana benthamiana and Prunus domestica. Acta Hortic 839:665-672

182. Wang H, Alburquerque N, Burgos L, Petri C (2011) Adventitious shoot regeneration from hypocotyl slices of mature apricot (Prunus armeniaca L.) seeds: a feasible alternative for apricot genetic engineering. Sci Hortic 128:457-464

183. Wang H, Petri C, Burgos L, Alburquerque N (2013) Efficient in vitro shoot regeneration from mature apricot (Prunus armeniaca L.) cotyledons. Sci Hortic 160:300-305

184. Wang H, Petri C, Burgos L, Alburquerque N (2013) Phosphomannose-isomerase as a selectable marker for transgenic plum (Prunus domestica L.). Plant Cell Tissue Organ 113:189-197

185. Weigel D, Alvarez J, Smyth DR, Yanofsky MF, Meyerowitz EM (1992) $L E A F Y$ controls floral meristem identity in Arabidopsis. Cell 69:843-859

186. Worrall D, Hird DL, Hodge R, Paul W, Draper J, Scott R (1992) Premature dissolution of the microsporocyte callose wall causes male sterility in transgenic tobacco. Plant Cell 4:759-771

187. Xing W, Wang Z, Wang X, Bao M, Ning G (2014) Overexpression of an FT homolog from Prunus mume reduces juvenile phase and induces early flowering in rugsoa rose. Sci Hortic-Amsterdam 172:68-72

188. Yabuta Y, Tanaka H, Yoshimura S, Suzuki A, Tamoi M, Maruta T, Shigeoka S (2012) Improvement of vitamin E quality and quantity in tobacco and lettuce by chloroplast genetic engineering. Transgenic Res 22:291-402

189. Yang Y, Singer SD, Liu Z (2011) Petunia AGAMOUS enhancerderived chimeric promoters specify a carpel-, stamen-, and petal-specific expression pattern sufficient for engineering male and female sterility in tobacco. Plant Mol Biol Rep 29:162-170

190. Yanofsky MF, Ma H, Bowman JL, Drews GN, Feldmann KA, Meyerowitz EM (1990) The protein encoded by the Arabidopsis 
homeotic gene agamous resembles transcription factors. Nature 346:35-39

191. Yao YX, Sun YW, Li GG, Li GH (2011) Regeneration of plants from in vitro culture of petioles in Prunus domestica Lindl (European plum). Biotechnol Equip 25:2458-2463

192. Yeoh C, Balcerowicz M, Laurie R, Macknight R, Putterill J (2011) Developing a method for customized induction of flowering. BMC Biotechnol 11:36. www.biomedcentral.com/14726750/11/36. Accessed Dec 2013

193. Yoshida H, Itoh JI, Ohmori S, Miyoshi K, Horigome A, Uchida E, Kimizu M, Matsumura Y, Kusaba M, Satoh H, Nagato Y (2007) superwoman1-cleistogamy, a hopeful allele for gene containment in GM rice. Plant Biotechnol J 5:835-846

194. Zagrobelny M, Bak S, Rasmussen AV, Jørgensen B, Naumann CM, Lindberg Møller B (2004) Cyanogenic glucosides and plant-insect interactions. Phytochemistry 65:293-306
195. Zhang JX, Fernando WGD, Remphrey WR (2005) Molecular detection of Apiosporina morbosa, causal agent of black knot in Prunus virginiana. Plant Dis 89:815-821

196. Zhang Y, Wu R, Qin G, Chen Z, Gu H, Qu LJ (2011) Overexpression of WOX1 leads to defects in meristem development and polyamine homeostasis in Arabidopsis. J Integr Plant Biol 53:493-506

197. Zheng L, Poulton JE (1995) Temporal and spatial expression of amygdalin hydrolase and (R)-(+)-mandelonitrile lyase in black cherry seeds. Plant Physiol 109:31-39

198. Zhou J, Hartmann S, Shepherd BK, Poulton JE (2002) Investigation of the microheterogeneity and aglycone specificity-conferring residues of black cherry prunasin hydrolases. Plant Physiol 129:1252-1264 